\title{
Epidemiology of Lymphoid Malignancy in Asia
}

\author{
Zahra Mozaheb \\ Mashhad University of Medical Science
}

Iran

\section{Introduction}

Lymphoid malignancy is a remarkable disease because of its difference in epidemiology and etiology in different areas around the world. Several features of the epidemiology of lymphoid malignancy particularly stand out. The overall lymphoid malignancy incidence in Asian countries is relatively low. Histopathologic subtypes of lymphoma are different in eastern and western countries and generally similar among Asian countries. Differences in geographic distribution are striking for follicular lymphoma, which is less common in eastern countries than elsewhere. Asians have higher rates of aggressive NHL (Non-Hodgkin Lymphoma), T-cell lymphomas, and extra-nodal disease. Hodgkin's Lymphoma (HL) is relatively rare in Asian countries, and its subtypes are various in comparison with other areas.

While for most cancers incidence and mortality are decreasing, the incidence rates of all subtypes of NHL have increased during the second half of the twentieth century, but the reason is poorly understood. This rise has been noted worldwide, in both genders, particularly in the elderly, and increase in high-grade NHL is predominant. Increase in NHL may be attributed to immunodeficiency, radiation, various infections, blood transfusion, familial aggregation, genetic susceptibility to NHL, chemical exposures to pesticides and solvents, and diet. Some studies also suggest that association between risk factors and specific NHL subtypes may be stronger than association between the same risk factors and NHL in aggregate. In addition the mentioned risk factors are different in various areas; therefore it may cause different distribution of lymphoid malignancy around the world. Geographic variation in lymphoma rate suggests the importance of environmental and gens effects. Risks for developing NHL include immunosuppression a causal link between infectious agents and lymphomagenesis, which have also been determined, particularly for human T-cell leukemia/lymphoma virus type1 (HTLV-1), Epstein-Barr virus (EBV), Helicobacter pylori infections and Hepatitis C Viruses (HCV)infection, which are relatively frequent in our area. In addition to the incidence of non-Hodgkin's lymphoma and its histological subtypes in Asian migrants to the United States which is lower in first-generation migrants, confirmed this suggestion. Other exogenous factors which have been implicated in lymphomagenesis, mentioned earlier, are used more without any protection in developing countries. They may play an important role in these differences.

In this chapter we compare our findings with the data from other relevant studies available in literature from various parts of Asia, as well as with those of Western countries in an 
attempt to gain more insights into the differences between the Oriental and Western countries. In addition, because most different are related to etiologic factors, we also describe some of them.

\section{Non-Hodgkin Lymphoma}

Non-Hodgkin lymphoma is a heterogeneous group of B-cell and T-cell neoplasm that arise primarily in the lymph nodes with varied clinical and biologic feature. Current classification system include the Revised European-American Lymphoma (REAL) classification and the World Health Organization (WHO) classification of hematopoietic and lymphoid neoplasms (Alexander, et al., 2007). The distribution of NHL types varies internationally (Anderson, Armitage, \& Weisenburger, 1998). Epidemiological investigation of the NHL and its etiology may result in a better understanding and hence prevention.

\subsection{Descriptive epidemiology}

Based on World Health Organization (WHO) classification,36 subtype of NHL (21 of B-cell and 15 of T-cell type) are recognized (Ekström-Smedby, 2006). NHL is the most common in the developed world, with the highest incidence in USA, Australia and New Zealand, and Europe, and the lowest in eastern and South central Asia (Ekström-Smedby, 2006). The age standardized incidence of NHL, around the year 2000, was estimated at approximately 1014 per 100000 person-year in western countries, and 3 per 100000 in South central Asia (Parkin, Bray, Ferlay, \& Pisani, 2005).

In recent decades, there has been a dramatic increase in NHL incidence worldwide, of about $2-4 \%$ annually (Baris \& Zahm, 2000). This increase has been occurred in both males and females in all age groups except the very young and in black and whites (Weisenburger, 1994). Racial differences have not been observed in age-specific incidence curves until the age of 45 for males and 35 for females, however over these ages, NHL develops more frequently in whites than blacks (Müller, Ihorst, Mertelsmann, \& Engelhardt, 2005). The highest increase was observed in western countries, but this increase is no limited to these countries, and it has been observed in eastern countries such as India, Japan, Singapore (Devesa \& Fears, 1992). Several reasons including: recategorisation of borderline type of lymphoma; less histopathological misdiagnosis of NHL as Hodgkin's disease; greater use of immunohistological techniques to examine cancer of uncertain cell type and coding effects, may account for part of the increase (A. J. Swerdlow, 2003). The general trends in western countries has been a dramatic increase in incidence in young men in areas where AIDS has become common (Morton, et al., 2006).

The median age of NHL in Asian countries is significantly lower, compared to the population-based registration in western countries. The Hematological Malignancy Research Network reported that the median age of their patients was 68 years old (Smith, et al., 2010). However the median age in Asian countries is about 54 years old, in Iranian patients was 55 years old (Mozaheb, Aledavood, \& Farzad, 2011), in the Korean patients 52 years (Y.-H. Ko, et al., 1998), in Taiwan 54 years (Lee, Tan, Feng, \& Liu, 2005), and in a previous study in Japan 54.5 years (Aozasa, et al., 1985), but in a recent study in Japan it was 66 years (Aoki, et al., 2008). It is notable that the median age of Asian patients at the time of presentation was younger than in the western countries and it might be attributable to the 
lower frequency of lymph node type lymphoma, and higher frequency of T-cell lymphoma, which comes as follows.

Geographically related variation in the incidence of histopathologic distribution and clinical feature of NHL are well recognized (Shih \& Liang, 1991). T-cell leukemia lymphoma occurs more frequently in southwest Japan, and the Caribbean basin (Takatsuki, 1990), northeast of Iran (Mashhad) (Abbaszadegan, et al., 2003); follicular lymphoma (FL) occurs less frequently in eastern countries (Intragumtornchai, et al., 1996; Mozaheb, et al., 2011; Ohshima, Suzumiya, \& Kikuchi, 2002), and Immunoproliferative Small Intestinal Disease (IPSID) is the most prevalent in the Middle east and Africa (Khojasteh \& Haghighi, 1990).

\subsubsection{Immunologic characterization of non-Hodgkin's lymphoma}

Although B-cell lymphomas are constantly more common around the world, T-cell lymphomas are proportionally more common in Asia than in western countries (Müller, et al., 2005). Despite a higher percentage of T-cell lymphomas in Asians compared with westerns, the absolute incidences of T-NHL in HTLV1 non endemic areas, and western countries are quite similar when calculated by age-adjusted incidence (Aoki, et al., 2008; Au, et al., 2005; Wang, Young, Win, \& Taylor, 2005). In a Chinese (non endemic area for HTLV1) study T-cell lymphoma proportion was $28.1 \%$ (Wang, et al., 2005), and also in Taiwan which is not endemic for HTLV1, T/NK lymphoma incidence was $12.4 \%$ (Lee, Tsou, Tan, \& Lu, 2005). In an Indian study T-cell lymphomas formed $16.2 \%$ of the total NHL (Naresh, Srinivas, \& Soman, 2000). Previous Japanese studies have reported a higher proportion of Tcell lymphoma, accounting for approximately 32-38\% of non-Hodgkin lymphoma (Kadin, Berard, Nanba, \& Wakasa, 1983; Pathologists, 2000), but the recent findings in Japan show the decreased frequency of T/NK cell lineage (25\%) (Aoki, et al., 2008). In endemic area for HTLV1 in Japan, T/NK-cell neoplasm accounted for a higher percentage of lymphoid neoplasm, in Kyushu (30\%) and Okinawa (38\%), compared with other areas of Japan (18$20 \%$ ) (Aoki, et al., 2008). In one study in 1997 in Korea, in comparison with data reported in 1992, the proportion of T-lineage lymphoma was markedly decreased (25\%). At that time, the T-lineage of lymphoma accounted for $35.2 \%$ of malignant lymphomas (Y. H. Ko, et al., 1998). It may be due to an increase in the frequency of B-cell lymphoma and an actual decrease in T/NK-cell, but the real reason remains unclear (Y. H. Ko, et al., 1998).

\subsubsection{Histological subtype of non-Hodgkin's lymphoma}

Diffuse Large B Cell Lymphoma. Among B-cell lymphomas, diffuse large B cell lymphoma (DLBCL) is the most common non-Hodgkin's Lymphoma representing approximately one third of all Non-Hodgkin's Lymphomas worldwide. This is one type of Non Hodgkin's Lymphoma in which the relative incidence does not seem to vary geographically (Mozaheb, et al., 2011). In almost all parts of the world this is the most frequent occurring nonHodgkin's lymphoma (K. E. Hunt \& Reichard, 2008). In some studies like a recent study in Mashhad, Iran (Mozaheb, et al., 2011) there was a higher rate of aggressive NHL specially, diffuse large B cell lymphoma which occurs more frequent than others. It may be related to the etiology of diffuse large B cell lymphoma such as immune deficient conditions and their treatments which in most instances caused aggressive non-Hodgkin's lymphoma, and we should consider that a comparative excess of DLBCL resulting in a deficit of follicular lymphoma. In addition genetic factors may have an important role in this difference. 
Moreover it can represent the progression/transformation (referred to as secondary) of a less aggressive lymphoma, such as follicular lymphoma, marginal zone B-cell lymphoma, or nodular lymphocyte-predominant Hodgkin's lymphoma (K. E. Hunt \& Reichard, 2008). All lymphoid cancers are more frequent in males than females among all age groups and in our study Diffuse large B cell lymphoma occurs about twice among men (Mozaheb, et al., 2011). This pattern suggests that the underlying environmental or behavioral factors are also important and must be more common in men. The most common subtypes of NHL in Various Geographic Locations are showed in table 1.

Follicular Lymphoma. Incidence rates of follicular lymphoma (FL) inexplicably vary markedly between Asian and Western countries (Biagi \& Seymour, 2002). Follicular lymphoma was found more frequently in North America and Europe compared to other geographic sites (Kim, et al., 1992). The lowest rates of follicular lymphoma have been reported among Asian population (Anderson, et al., 1998; Mozaheb, et al., 2011). In addition, the risk was lower for the first generation of migrants from China and Japan into the US in comparison with the subsequent migrant generations, and in Japanese-Americans in Hawaii it was reported to be relatively high compared with that for native Japanese and close to the rate of North American Caucasians (Yanagihara, Blaisdell, Hayashi, \& Lukes, 1989). The percentage of follicular lymphoma in our study in Mashhad, IRAN, was the lowest observed in any site (1.4\%) (Mozaheb, et al., 2011), it was near the incidence rate of NHL in a previous study in Korea (1.6) (Y. H. Ko, et al., 1998). Although the exact reason for this difference is unknown, the results of several studies suggest differences in genes and environmental factors such as diet habits, infections and smoking, which plays an important role in follicular lymphoma, are responsible. Some cytogenetic changes such as a higher incidence of bcl-2 translocations are seen within follicular lymphoma among individuals in the US than for Asian populations (Shih \& Liang, 1991). It conclude that a significant gradient exists in the $b c l-2$ frequency between these FL populations, and therefore suggest that the relatively low incidence of FL in Asian populations is caused not by a lower frequency of $b c l-2$ rearrangements in healthy populations but by distinct molecular pathways developing in different geographic regions that nonetheless culminate in FL, which is morphologically similar but molecularly distinct (Biagi \& Seymour, 2002).

In a previous study in Japan the incidence rate of FL was 6.7\% (Pathologists, 2000), but in a recent study in Japan they found a relatively high rate of FL (19\%) similar to that of western countries (11-30\%) (Aoki, et al., 2008). They suggest the following reasons for the relatively high rate of occurrence of follicular lymphomas. First, there have been improvements in the recognition and diagnostic accuracy for this subtype due to the development of comprehensive diagnostic methods including flow cytometry, immunohistochemistry, chromosome testing, gene testing and FISH. Second, the patients in their recent study comprised only initial visit cases and did not include consultation cases, because typical follicular lymphoma tends to be diagnosed at the initial visit and not during consultation, previous studies of patients in large hospitals may not have included initial visit cases and thus underestimated the frequency of follicular lymphoma. The third reason is the westernization of the Japanese lifestyle that may have contributed to an increase in follicular lymphoma (Aoki, et al., 2008). The rate of follicular lymphoma for Japanese- Americans in Hawaii was reported to be relatively high compared to that of native Japanese and close to the rate of North American Caucasians. A similar trend in completely follicular lymphoma has been reported for Korea. In one study in 1997 compared with the data reported in 1991, 
the increase in the relative frequency of Fl (1.6\% vs $6.4 \%)$ over time suggests that the patterns of malignant lymphoma occurrence in the Republic of Korea might be gradually changing, probably due to westernization and other reasons which were mentioned previously (Y. H. Ko, et al., 1998).

\begin{tabular}{|c|c|c|c|c|c|c|c|c|c|c|}
\hline $\begin{array}{l}\text { Country/ } \\
\text { year }\end{array}$ & 2010 & 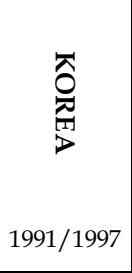 & $\frac{\sum_{2}^{\exists}}{\text { Z }}$ & $\begin{array}{l}\underset{Z}{Z} \\
\underset{B}{D} \\
2000\end{array}$ & $\underset{2005}{\stackrel{O}{Z}}$ & $\begin{array}{l}\text { 甼 } \\
\text { 蛋 } \\
2004\end{array}$ & 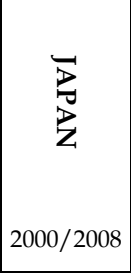 & 1991 & 2001 & $\begin{array}{l}\mathcal{E} \\
D \\
2006\end{array}$ \\
\hline Total (No) & 391 & $1165 / 1548$ & 年--/598 & & 447 & 1983 & $3025 / 2260$ & 9567 & 10580 & \\
\hline NHL \% & 92 & $94.7 / 94.7$ & $\begin{array}{l}---/ 93 \\
\end{array}$ & 2831 & $82.6 \%$ & $92.1 \%$ & $94 / 7 / 92.7$ & & 84.4 & \\
\hline $\mathrm{B} / \mathrm{T}$ cell $\%$ & & $75 / 25$ & $\begin{array}{l}81.7 / 18.3 \\
80.6 / 19.4 \\
\end{array}$ & $79 / 15.2$ & $68.6 / 30.6$ & $75 / 25$ & $\begin{array}{c}68 / 24, \\
65.2 / 25.4 \\
\end{array}$ & $76 / 24$ & $93 / 7$ & $90 / 10$ \\
\hline DLBCL \% & 37.8 & $-/ 43.2$ & $47.2 / 39$ & 34 & 35.1 & 50.5 & $33 / 33$ & 41.2 & 41.3 & 28 \\
\hline FL \% & 1.4 & $1.6 / 6.2$ & $8.6 / 16.4$ & 12.6 & 8.6 & 8.4 & $6.7 / 18.2$ & 9.2 & 17 & 13 \\
\hline MCL \% & 2.2 & $-/ 1.5$ & $----/ 4$ & 3.4 & 2.6 & 1.5 & $2.7 / 2.7$ & & 3.7 & 2 \\
\hline $\begin{array}{l}\text { MALT } \\
\text { lymphoma\% }\end{array}$ & 2.2 & $-/ 0.6$ & $6.1 / 5.6$ & 8.2 & 11.7 & 5.5 & $8.4 / 4.2$ & 8.7 & 3.6 & 3.7 \\
\hline SLL/CLL \% & 23.9 & $-/ 2.3$ & & 5.6 & 3.6 & 3.4 & $1.4 / 1.4$ & & & 20 \\
\hline $\begin{array}{l}\text { NK/T cell } \\
\text { lymphoma \% }\end{array}$ & & & $----/ 12.4$ & 0.9 & 30.6 & & 1.5 & & & 5 \\
\hline $\begin{array}{l}\text { Peripheral T } \\
\text { cell lymphoma } \\
\%\end{array}$ & 1.9 & $-/ 9.4$ & $19.3 / 3.8$ & 1.9 & 12 & 13.1 & $6.6 / 4.5$ & 9.7 & 5.9 & 6 \\
\hline \begin{tabular}{|l|l} 
ATLL $\%$ \\
\end{tabular} & 1.4 & $-/ 0.1$ & & rare & rare & & $7.4 / 10$ & & rare & rare \\
\hline HL \% & 8 & $5.3 / 5.3$ & $----/ 7$ & & 13.9 & 7.9 & $4.4 / 7.3$ & & 15.6 & 8 \\
\hline
\end{tabular}

Table 1. The Most Common subtypes of NHL in Various Geographic Locations

In the analysis of 1983 cases of malignant lymphoma in Thailand shows that Bangkok has a significantly high frequency of FL, much higher than that the Central region. They suggest that the underlying reason for this observation is not known. Obviously, Metropolitan Bangkok has a more diverse population, migrated from various geographical locations, than people in the Central region (Sukpanichnant, 2004). A clinicopathological analysis of 598 Malignant Lymphomas in Taiwan during the period of 1995-2002 was retrieved, and their data showed a similar incidence of FL $(16.4 \%)$ to that in Western countries (Lee, Tan, et al., 2005).

Mantle cell Lymphoma (MCL) in a case series has been between 2 and $10 \%$ of all NHL. The incidence rate is approximately similar around the world (table 1) and it is about 0.5 cases per 100000 person-year, with male to female ratio 2.3-2.5:1, and median age at diagnosis is about 70 years. Relative association of MCL risk with Borrelia burgdorferi infection, family history of hematopoietic malignancies, and genetic variation in the interleukin 10 and tumor necrosis factor genes have been reported, but finding remain unconfirmed (Smedby \& Hjalgrim., 2011). 
T cell lymphomas are very complicated, based on WHO classification, there are various subtypes, and different types of them are different in various area of the world and some are extremely rare, occurring in a few patients per year throughout the world. Major T cell NHL types were reported in the international study in about 1300 patients 22 sites in different countries. Based on this study the most common subtype of $\mathrm{T}$ cell lymphoma in North American (NA) was PTCL (unspecified), in Europe was Angioimmunoblastic $\mathrm{T}$ cell lymphoma (AITL), and in Asia was Natural Killer T cell lymphoma (NKTCL) and ATLL (Foss, et al., 2011). This variation may reflect exposure or genetic susceptibility to pathogenic agents such as EBV and HTLV1 in Asian countries. Table 2 showed the major T cell subtype of NHL in different area (Vose, et al., 2008).

\begin{tabular}{|l|c|c|c|c|c|}
\hline$\%$ & PTCL & AITL & Anaplastic & NKT CL & ATLL \\
\hline NA & $\mathbf{3 4 . 4}$ & 16 & 23.8 & 5.1 & 2 \\
\hline Europe & 34.3 & $\mathbf{2 8 . 7}$ & 15.8 & 4.3 & 1 \\
\hline Asia & 22.4 & 17.9 & 5.8 & 22.4 & $\mathbf{2 5}$ \\
\hline
\end{tabular}

Table 2. Major subtype of T cell lymphoma by region

Generally speaking an increasing incidence in lymphoma reported from western countries is also seen in Asia, albeit at a lower rate (Shih \& Liang, 1991).Essential differences in the incidence and distribution of major NHL subtypes among different geographic areas were seen which seems to be related to host, racial and environmental differences (Atichartakarn, et al., 1982), but these differences gradually changes in recent reports, this shows that the environmental factors probably are more important than the genes.

\subsubsection{Extra-nodal non-Hodgkin Lymphoma}

Non-Hodgkin lymphoma arises in lymphatic cell in other organs except lymphatic tissues, called extra-nodal lymphoma. Some authors believe that, specific local factors may play an etiologic role in the development of lymphomas at certain extra-nodal sites e.g., Helicobacter pylori infection is associated with primary gastric lymphoma, but not with lymphoma at other sites (Parsonnet, et al., 1994b; Wotherspoon, et al., 1993). There are geographical and ethnic differences in the incidence of extra-nodal lymphomas (Newton, Ferlay, Beral, \& Devesa, 1997).

The frequency of primary extra-nodal NHL in Asia Varied from 28.5 to $45 \%$ (Shih \& Liang, 1991), it is similar to Europe, but slightly more common than united states: Denmark 37\% (d'Amore, et al., 1991), India 22\% (Advani, et al., 1990), Hawaii-Japanese 34\% (Yanagihara, et al., 1989), Lebanon 44\% (P. Salem, et al., 1986), Chinese Hong Kong 28\% (Ho, Todd, Loke, $\mathrm{Ng}$, \& Khoo, 1984), USA 25\% (Freeman, Berg, \& Cutler, 1972), Italy 48\%, East Germany $47 \%$ (Newton, et al., 1997).

The incidence of extra-nodal NHL in Western countries has increased substantially in the last 40 years. This may be due to improved diagnostic procedures (particularly in gastrointestinal and brain lymphomas) and changes in classification systems, but the change is real and the AIDS epidemic in the 1980s does not completely explain this rise (Groves, Linet, Travis, \& Devesa, 2000). The etiology of extra-nodal lymphomas appears to be multifactorial and includes immune suppression, infections both viral and bacterial, and exposure to pesticides and other environmental agents (Zucca, 2008). True geographic 
differences are, however, present for example, the incidence of Epstein-Barr virus and human T-cell lymphotropic virus 1-associated with T-cell lymphomas is higher in Asia than in Europe and North America (Zucca, 2008).

One study, which was done in 39 centers in 14 countries (USA, Europe, Asian) reported the most frequent extra-nodal sites of lymphoma are stomach and skin, followed by small intestine and tonsil (Newton, et al., 1997). In recent study extra-nodal lymphoma in Japan, was seen in $27 \%$ of cases, but in previous Japanese series it was 60\% (Izumo, 1996). DLBCL was the most common type of extra-nodal lymphoma lesion primarily biopsied/resected $(60 \%)$. The ear-nose-throat region $(7.2 \%)$, gastrointestinal tract $(6.0 \%)$, soft tissue $(2.8 \%)$ and skin $(2.6 \%)$ was reported in Japanese study (Aoki, et al., 2008). A clinical analysis in Republic Korea revealed that the rate of extra-nodal lymphoma exceeded that of lymph node lymphoma (63.3\% vs. 36.7\%) (Y.-H. Ko, et al., 1998). As in other Far East countries, Korea has a relatively high rate of angiocentric lymphomas, which more than $70 \%$ of them arise in the nose and paranasal sinus. EBV was positive in $80 \%$ of nasal and paranasal angiocentric lymphomas. (Ko \& Lee, 1994, 1996). In a study in Thailand, extra-nodal involvement was found in 1072 of 1826 cases (58.7\%) of NHL. The frequency of B-cell NHL in cases of NHL involving extra-nodal sites was $72.9 \%$, whereas the frequency of nodal Bcell NHL was $78.0 \%$. Thus, a higher frequency of T-cell NHL involving extra-nodal sites and a higher frequency of B-cell NHL involving lymph nodes were significant when compared to the overall NHL $(P<0.05)$. In the Thailand study, among the extra-nodal sites involved in $\mathrm{NHL}$, the upper aerodigestive tract (including the tonsils, sinonasal region, oral cavity, and nasopharynx) was the most common site. The second most common site was the gastrointestinal tract, including the stomach and intestine (Sukpanichnant, 2004). These studies shows that extra-nodal NK/T cell lymphoma is more prevalent in far east and is closely related to EBV infection (Jaffe, 1999; Jaffe, et al., 1996).

Immunoproliferative small intestinal disease (IPSID) or a heavy chain disease is mostly found in young adults of low socioeconomic class in developing countries or in indigent immigrant population within western countries. Relatively high incidence rates of small intestinal lymphoma have been reported before in the Middle east, Mediterranean region, South and central Africa, Mexico, and South America, but is rare in Southeast Asia (Pramoolsinsap, Kurathong, Atichartakarn, \& Nitiyanand, 1993).

IPSID was one of the most common small intestinal malignancy in the Middle East (Azar, 1962). Early infectious stress in infancy and chronic antigenic stimulation along with genetic factors are probably important in the pathogenesis of IPSID (Khojasteh, Haghshenass, \& Haghighi, 1983). It showed that Campylobacter jejune were present in 5/7 cases of IPSID in one study and 12/27 (47\%) cases in other and 14/87 (16\%) cases of other intestinal lymphoma. Eradication of the organism with antibiotics lead to complete remission of IPSID (Du, 2007).

In one series of 161 patients with IPSID in Shiraz (Iran), they observed a dramatic decrease in the incidence of the disease over the past decade. After the Islamic revolution in Iran, improving sanitation in villages was one of the priorities of the many health strategies in Iran. Access to sanitary drinking water in rural areas increased from 35\% before 1988 to $80 \%$ a decade later. Vaccination programs increased dramatically after the Islamic revolution, reaching more than $90 \%$ of children. Local health facilities increased significantly during the first two decades after the revolution. They suggest that improvement of health in general 
and decreasing childhood gastroenteritides in particular has resulted in a decrease in the incidence of IPSID. This report highlights the almost complete disappearance of a malignant disease from a region where it was once very common. This changes probably related to changes in environmental factors, decreasing exposure to infectious agents (Lankarani, et al., 2005). Other preliminary recent epidemiological data has also shown a decrease in the incidence of this disease in endemic areas; therefore, environmental factors are suspected to play an important role in its pathogenesis (P. A. Salem \& Estephan, 2005).

\subsection{Epidemiologic etiology}

\subsubsection{Immunodeficiency and autoimmune disease}

Immunodeficiency, including acquired conditions and congenital disease, is the strongest factor known to increase NHL risk (Chiu \& Weisenburger, 2003). About 25\% of patients with congenital immunodeficiency syndromes such as Wiskott-Aldrich syndrome, ataxia telangiectasia and severe combined immunodeficiency, will develop tumors during their lifetime, which NHL accounting for $50 \%$ of them. It seems that these patients unable to promptly eliminate respiratory and gastrointestinal pathogens due to defects in formation of specific protective antibodies and are susceptible to chronic antigenic stimulation (Filipovich, Mathur, Kamat, \& Shapiro, 1992).

High rate of NHL also have been observed among individual with iatrogenic immunosuppression (i.e. organ or blood stem cell transplantation recipients, long term survivors of Hodgkin's lymphoma), variety of autoimmune disease, and Acquired immunodeficiency syndrome (AIDS). Although immunosuppressive drug use in the treatment of these conditions may cause an increase in NHL incidence, evidence suggests that the persistent inflammatory activity of the autoimmune process may have a direct relation with increase risk of lymphomagenesis. One study showed that these conditions may be accompanied by impaired T-cell function, which interferes with an immune response to virus and emerging malignant cells. NHL due to secondary immunodeficiency is associated with the presence of EBV infection, and tumors are characterized by high grad, and proclivity for extra-nodal sites (Fisher \& Fisher, 2004). Based on these data immunodeficiency may be more common in some area which aggressive lymphoma is more common such as Asian countries.

Autoimmune disorders that are strongly associated with NHL are Sjogren's syndrome, systemic lupus erythematosus (SLE), rheumatoid arthritis, and celiac disease (CD). There is no evidence to support excess risk of NHL in other autoimmune disorders. One study demonstrated a 25-fold increase in the risk of NHL among persons with highly inflammatory RA as compared to a similar group having low inflammatory disease; this risk was independent of treatment (Fisher \& Fisher, 2004). Finding in the other study suggests that the excess risk of NHL in RA patients may be a result of the disease or its treatment, rather than shared genetic susceptibility (Ekström, et al., 2003; Kinlen, 1992).

Celiac disease is an autoimmune digestive disease which is caused by an immune response to the protein gluten. Untreated CD is associated with increased risk of lymphoma, mostly with origins from gastrointestinal mucosa. The pathogenesis behind this association is not fully understood, but greater permeability to environmental carcinogenesis, release of proinflammatory cytokines, and chronic antigenic stimulation are among the suggested 
mechanisms. Also a correlation between the duration of gluten exposure and the incidence of lymphoma has been found. The relative risk of lymphoma is reduced by a gluten free diet (Jafroodi, Zargari, \& Hoda, 2009). In a US cohort study, an increased risk of NHL was reported in patients with celiac disease $(\mathrm{SMR}=9.1,95 \% \mathrm{CI}$ : 4.7-13.0). Similarly, a relative risk of 5.8 (95\% CI: 1.58-14.86) was observed in a UK cohort (Alexander, et al., 2007).

The incidence of $\mathrm{CD}$ is increasing among certain populations in Africa (Saharawui population), Asia (India), and the Middle East (Cummins \& Roberts Thomson, 2009). In Asian populations, including the Japanese, CD and the associated NHL have been supposed to be quite rare, and studies concerning the frequency of CD or its relationship with NHL are scarce. A Japanese case report describes a Japanese middle-aged man with intestinal diffuse large B-cell lymphoma associated with CD. Following multi-combined chemotherapy, the patient's lymphoma has received complete response, and his GI symptoms have improved with a gluten free diet (Makishima, et al., 2006). Also an Iranian case report describes a child with Hodgkin's disease and sever atopic dermatitis associated with CD (Arellano, et al., 2009). These cases suggest that the possibility of CD and its association with lymphoid malignancy should be kept in mind, even in Asian populations.

\subsubsection{Infectious agents}

Epidemiological studies pointed towards a viral and bacterial etiology on NHL. In this part we discuss about some of them which are more important.

Epstein-Barr virus (EBV). The Epstein-Barr virus has a worldwide distribution, which greater than $80 \%$ of people over the age of 30 are infected. Once $E B V$ infection has occurred, it remains for the lifetime of the individual (Serraino, et al., 2005). Infection with this virus usually occurs in children, but can also occur in adolescence or adulthood. $E B V$ asymptomatically establishes persistent infections however, due to effective immune control, only a minority of infected carriers develop spontaneous $E B V$-associated lymphoma (Heller, Steinherz, Portlock, \& Munz, 2007). Infection by $E B V$ is more common in developing countries where sanitation, hygiene, and cooking are not as sterile as nations such as the USA (Evans \& Kaslow, 1997).

$E B V$ has a unique set of genes that causes a growth activation of the B-cells that are infected. Sometime the growth activating genes may cause the infected B-cell to transform into cancer in certain people. The most common type of lymphoma caused by EBV are T-cell lymphoma, Post-transplant lymphoma, AIDS associated lymphoma, Burkitt's lymphoma (BL), and Hodgkin's lymphoma. These EBV-associated neoplasms are characterized by peculiar geographic distributions and distinctive epidemiologic features (Serraino, et al., 2005) .

In the endemic areas of Africa, BL is the leading childhood cancer, occurring as many as 4-5 cases per 100000 . In areas where $E B V$ infection occurs at a very early age and malaria is holoendemic, the incidence of association with BL is highest. In African countries in the lymphoma belt there is a very high association between BL and EBV (90\%). However, in France and the US, the rare cases of BL are only associated with $E B V$ in $10-15 \%$ of all reported cases (Frimpong-Boateng).

Induced immunosuppretion, necessary for the transplant to be accepted, leads to a loss of control over $E B V$ infection. The lymphoma that is developed contains parts of the latent $E B V$ genome. About half of NHL tumors accompanying HIV1 infections are EBV positive. 
These lymphoma are grouped into several categories: small non-cleaved-cell lymphoma, diffuse large cell lymphoma, anaplastic large cell lymphoma, and body-cavity based lymphoma (Gaidano, et al., 1996).

Several studies showed the association of Asian T cell lymphoma and evidence of $E B V$ infections. Asian T-cell lymphomas are different from Western T-cell lymphoma, and are also associated with increased levels of cytokine production, including tumor necrosis factor (Dutcher, 2003). Aggressive NK-cell LGL leukemia is usually a rapidly progressive disorder associated with EBV, with a higher prevalence in Asia and South America (Sokol \& Loughran, 2006).

Human T-Cell Lymphotrophic virus-1 (HTLV1). HTLV1, the first human retrovirus to be discovered, is estimated to infect 10-20 million people worldwide (De The \& Bomford, 1993). Infection with HTLV1 is strongly related to adult T-cell leukemia/ Lymphoma (Hinuma, et al., 1981) and HTLV1 associated myelopathy (Morgan, Mora, Rodgers-Johnson, \& Char, 1989). HTLV1 is primarily transmitted by breast feeding, blood transfusion, Sharing of needles and sexual transmission. The predominance of vertical transmission results in clustering cases in familial or geographically discrete groups. It is endemic in southern Japan, the Caribbean, the Melanesian island, Papua New Guinea, the Middle East, central and southern Africa, and South America. In these endemic areas, seroprevalences range are different from about one percent in Mashhad in southeast Iran (1-3\%) (Abbaszadegan, et al., 2003; Tarhini, et al., 2009) to 30 percent in rural Miyazaki in southern Japan. In table 3 we can see the prevalence rate of HTLV1 in different countries.

Population HTLV-I seroprevalence increases with age and is twice as high in females. In Jamaica $17 \cdot 4 \%$ of women over 70 and $9 \cdot 1 \%$ of men over 70 were seropositive. In Japan, HTLV-I seroprevalence in persons over 80 was $50 \%$ in females and $30 \%$ in males. This gender difference usually emerges after 30 years of age and may be related to more efficient transmission of the virus from males to females in the sexually active years (Yamaguchi, 1994). Seroprevalence tends to increase with age and women are nearly twice as likely to be infected as men (Mueller, Okayama, Stuver, \& Tachibana, 1996).

HTLV1 shows little genomic variability during the course of infection and between patients in the same geographic area. Mother/child and spouse pairs from Okinawa (Japan) have been shown to be infected with highly conserved viruses upon direct sequencing of viral genome (Kakuda, Ikematsu, Chong, Hayashi, \& Kashiwagi, 2002). Studies in France (Gessain, Gallo, \& Franchini, 1992) the Solomon Islands (Nerurkar, Song, Saitou, Melland, \& Yanagihara, 1993) and Zaire (LIU, et al., 1994) have shown similarly low genomic variability based upon the less accurate sequencing of PCR products. Therefore, small strain variation is recognized between geographic areas. Risk of infection is higher (fourfold increase) in breast fed infants than in those who are bottle fed (HIRATA, et al., 1992). A longer duration of breast feeding increase transmission risk (Li, et al., 2004). Another important risk factor is provirus load in breast milk.

The infection is usually asymptomatic in the beginning and the disease typically manifests later in life; therefore silent transmission occurs. Since there are no prospects of vaccines and screening of blood banks and prenatal care settings are not universal, transmission is active in many areas such as parts of Africa, South and Central America, the Caribbean region, Asia, and Melanesia (Goncalves, et al., 2010). 


\begin{tabular}{|l|c|c|c|}
\hline country & Sample size & Prevalence of HTLV1 & Group \\
$\begin{array}{l}\text { rural Miyazaki, } \\
\text { southern Japan }\end{array}$ & & Up to $30 \%$ & General population \\
\hline Iran (Mashhad) & 1653 & 2.1 & General population \\
\hline Lebanon & 3529 & 0.06 & Blood donors \\
\hline Taiwan & 3700000 & 0.06 & Blood donors \\
\hline Korea & 9281 & 0.13 & Blood donors \\
\hline Jamaica & & $3-6 \%$ & General population \\
\hline Caribbean & & $6 \%$ & General population \\
\hline Curacao & 2524 & $1.92 \%$ & General population \\
\hline Papua New Guinea & 1221 & $0-14.6 \%$ & General population \\
\hline Argentina & 2082 & $1.9 \%$ & Blood donors \\
\hline U.S & 1700000 & 0.01 & Blood donors \\
\hline Italy & 14598 & 0.03 & Blood donors \\
\hline Germany & 100852 & 0 & Blood donors \\
\hline U.K & 570609 & 0.001 & \\
\hline
\end{tabular}

Table 3. Prevalence of HTLV1 in different countries

Adult T-cell lymphoma leukemia (ATL) is an aggressive lymphoproliferative malignancy, with short survival in its acute form and an incidence of less than $5 \%$ in $H T L V$-1-infected people (Shimoyama, 1991). The cumulative incidence of ATL among Japanese HTLV1 carrier is about $2.5 \%$ (3-5\% in male and $1-2 \%$ in female). Although women are more infected with HTLV1, but ATL is more common in men, it shows that other factors also should be responsible. At first ATL was described in Japan and later in the Caribbean region and South America (Uchiyama, Yodoi, Sagawa, Takatsuki, \& Uchino, 1977). In the United States and Europe, ATL was diagnosed in immigrants from regions of endemicity. ATL occurs at least 20 to 30 years after the onset of HTLV-1 infection and is more common in adult males. Individuals infected in childhood may be at a higher risk of developing ATL (Pawson, et al., 1998). The occurrence of ATL in the fourth decade predominates in Brazil and in Jamaica (Proietti, Carneiro-Proietti, Catalan-Soares, \& Murphy, 2005), but in Japan, the fifth decade of life is predominant for the occurrence of ATL (Shimoyama, 1991). Possibly, local factors play a role in disease pathogenesis.

Helicobacter pylori (H. pylori). Helicobacter pylori colonizes gastric mucosa, leading to chronic Gastric infection, and induce peptic ulcer disease and gastric carcinoma, also may cause Bcell lymphomas, particularly mucosa-associated lymphoid tissue (MALT) tumors in the stomach, with the association being strongest in early lesion (Chiu \& Weisenburger, 2003; Zucca, et al., 2000). In developing countries, where over $90 \%$ of the population may be infected, H. pylori infection usually occurs during childhood with chronic infection continuing throughout adulthood (Pounder \& Ng, 1995). In contrast, although in developed countries the overall prevalence generally remains lower than in developing countries, the prevalence is low among children and rises with age in adults. H. pylori has been detected in more than $90 \%$ of patients with low-grade gastric MALT lymphoma, and in $40-75 \%$ of highgrade gastric lymphomas (Boot \& Jong, 2002).

Direct fecal oral transmission is predominant in industrialized countries whereas other transmission routes such as contamination of water may be more important in developing 
countries. The bacteria is transmitted within families in early childhood (Farinha \& Gascoyne, 2005). Parsonnet et al. (Parsonnet, et al., 1994a) and Vineis et al. (Vineis, et al., 1999) reported a significant positive association between $H$. pylori infection and risk of gastric NHL but not non-gastric NHL. Greater than $60 \%$ of MALT lymphomas regress with H. pylori eradication following treatment with antibiotics (R. Hunt, Sumanac, \& Huang, 2001). Because the US prevalence of $H$. pylori infection is low and declining, H. pylori most likely did not play a significant role in the overall rising trend of NHL incidence in the US (Alexander, et al., 2007). H. pylori infection is more common in Asian countries, therefore as we can see in table 1, MALT lymphoma in most Asian countries are more common than western countries.

Hepatitis C Virus (HCV). Hepatitis C virus infection has been reported to be a prevalent disease since the second half of the $20^{\text {th }}$ century (Strickland, 2006). Infection in different parts of Asia is similar, with an average seroprevalence of hepatitis $C$ antibody less than $2.5 \%$ in the general population. The major routes of $H C V$ transmission in Asia have been through blood transfusions and intravenous drug use, similar to the other countries. Other possible routes of transmission are medical intervention, tattooing, acupuncture, vertical and sexual transmission, accidental needle-stick and household contact. It is believed that HCV is still spreading in some areas of Asia because of the lack of routine screening of donated blood (Kao \& Chen, 2000). HCV has been linked to lymphomagenesis in people with and without type II mixed cryoglobulinemia (Saadoun, Landau, Calabrese, \& Cacoub, 2007). Increasing evidence indicates that the association between $H C V$ infection and lymphoma may be due to viral infection related chronic antigenic stimulation. The chronic inflammation pathway would be consistent with the association between $\mathrm{HCV}$ and several types of lymphomas and with the regression of some lymphoma after eradicating the $H C V$ infection (Hermine, et al., 2002; Vallisa, et al., 2005). One study showed that the association between HCV infection and risk of NHL subtypes included mostly countries with low background HCV prevalence. This study showed increased risks of DLBCL, marginal zone lymphoma and lymphoplasmacytic lymphoma associated with HCV infection (De Sanjose, et al., 2008). Another study revealed that there is no association between NHL and HCV infection (King, Wilkes, \& DIAZ ARIAS, 1998). Prevalence of HCV in series of patients with NHL in studies from different countries was various, it was more common in Italy and Japan (Armstrong, et al., 2006). Based on these studies there are marked regional differences in the prevalence of hepatitis $C$ infection in non-Hodgkin lymphoma. It seems that other factors including genetics, race, hormonal, and immunologic factors are required for malignant transformation. Several studies showed the frequency was higher in older women. Lymphoma associated with $\mathrm{HCV}$ infection more frequently present as primary extra-nodal lymphoma, especially in the liver, spleen and salivary glands (Armstrong, et al., 2006).

Human Immunodeficiency Virus (HIV). The relationship between human immunodeficiency virus/acquired immunodeficiency syndrome (HIV/AIDS) and the risk of developing NHL has been observed with strong positive associations in numerous studies. (Hooper, Holman, Clarke, \& Chorba, 2001; Ragni, et al., 1993). The relative risk of NHL among persons infected with HIV has been reported to be over 100, (Coté, et al., 1997; Goedert, et al., 1998) with the greatest risk for B-cell lymphomas and high-grade histology (Coté, et al., 1997; A. Swerdlow, 2003). Chronic antigenic stimulation and immune deficiency may be responsible for the increased risk of NHL among $H I V$-infected persons. HIV may act by inducing immunodysregulation, affecting genes responsible for cell regulation and failing to control 
other viruses, which may result in opportunistic infection and replication of oncogenic viruses (Coté, et al., 1997). In AIDS patients NHL has been reported in approximately 2-3\% of patients with AIDS, but AIDS accounts only for a small fraction of all NHL (Biggar \& Rabkin, 1992; Rabkin \& Yellin, 1994). In an international collaboration on HIV and cancer, incidence data from 23 prospective studies were used to compare incidence rates of NHL in $H I V$-infected persons in 1997-1999 with those in 1992-1996 (Coutinho, 2000). The incidence rates for NHL declined from 6.2 per 1,000 person-years to 3.6 per 1,000 person-years. Grulich et al. (Grulich, et al., 2001) reported a significantly lower relative risk of NHL in persons with HIV in the period of highly active antiretroviral therapy (HAART) availability than in the period immediately prior ( $R R=0.58,95 \% \mathrm{CI}$ : 0.36-0.92) (Alexander, et al., 2007).

In one study in Japan the incidence of AIDS-related lymphoma detected at autopsy was higher in Japan (27\%) than in the US (12\%). However, histological subtypes of AIDS-related lymphoma in Japan seem to be similar to those in western countries and DLBCL is also the most common subtype of AIDS-related lymphoma in Japan. A large number of AIDSrelated lymphoma cases were categorized into EBV-associated opportunistic lymphoma in Japan. The incidences detected by autopsy did not differ statistically between the preHAART era and the HAART era $(P=0.31)$, and the histological subtype of DLBCL was stable in both the pre-HAART era $(78 \%)$ and the HAART era $(77 \%)$. In contrast, they found an increase in patients with BL from $2 \%$ in the pre-HAART era to $13 \%$ in the HAART era. (Hishima, et al., 2006). Despite the high rate of human immunodeficiency virus infection in Thailand, only 5 cases of documented AIDS-associated lymphoma were noted in one study (5 of 389 NHL; 1.3\%). Similarly, Kaposi's sarcoma is not common in AIDS patients in Thailand. The underlying reason for this unique feature of AIDS-related lymphoma in Thailand is not known and further investigation is needed (Sukpanichnant, et al., 1998). In one study in India the proportional incidence ratio (PIR) for NHL was significantly increased in HIV era (PIR in males $=17.1,95 \%$ CI 13.33-21.84, females $=10.3$, 95\% CI 6.1017.41), and their finding was similar to that reported by other studies (Dhir, et al., 2008). In one study in Singapore when comparing the age-standardized rates for males and female in 1998 - 2002 which are 8.2 and 5.0 per 100,000 respectively compared with 7.5 and 4.4 per 100,000 in 1993-1997 and 3.1 and 1.9 per 100,000 in 1968-1972, this may be partly due to HIV/AIDS, changes in pathological classification and improved diagnostic capabilities (Seow \& Registry, 2004). Except for one study in Thailand, HIV/AIDS lead to increase incidence rate of lymphoma in both eastern and western countries.

Human herpesvirus-8 (HHV-8). Human herpesvirus-8, is endemic in regions of the Mediterranean and Africa (Kamiyama, et al., 2004), but the seroprevalence of HHV-8 which has been studied in Malaysia, India, Sri Lanka, Thailand, Trinidad, Jamaica and the USA, in both healthy individuals and those infected with HIV, was found to be low in these countries in both the healthy and the HIV-infected populations (Ablashi, et al., 1999). HHV-8 is generally accepted to be associated with development of primary effusion lymphoma (PEL), a rare B-cell lymphoma that almost exclusively affects $H I V$-positive patients (Ascoli, et al., 2002). However this lymphoma is often associated with both $H H V-8$ and $E B V$, limiting the understanding of the pathogenic role of HHV-8 (Ascoli, et al., 2002). Within B-cell lymphomas, however, $H H V-8$ infection was associated significantly and positively with risk of lymphoplasmacytic lymphoma (OR $=4.47,95 \%$ CI: 1.34-14.85) or low-grade B-cell lymphoma and lymphoma not otherwise specified $(\mathrm{OR}=5.82,95 \% \mathrm{CI}$ : 1.07-31.73) (Feuillard, et al., 1997). 
Simian Virus 40 (SV40). Simian Virus 40 is the most well characterized member of the Polyomaviridae family, and is closely related to two human polyomaviruses (Poulin \& DeCaprio, 2006).It induces an inapparent infections in immunocompetent hosts, but can produces pathologic effects in immunocompromised individuals through the destruction of infected cells (Imperiale, 2000).Simian virus 40, an agent that infects Asian ma- caques, contaminated the early poliovirus vaccines used in the United States, Europe, and other region during the mass immunization program for poliovirus in the late 1950 and early 1960 (Strickler, et al., 2003). The Norwegian study shows that between 1953 and 1997, the incidence rate of lymphoproliferative diseases increased about 3-fold in both males and females (Thu, et al., 2006), and the other study report that polyomavirus SV40 is significantly associated with non-Hodgkin lymphoma in HIV-1-infected and HIV-1-uninfected patients and might have a role in the development of these hematological malignancies (Vilchez, et al., 2002). These observations suggest that polyomavirus SV40 might be causing infections in human beings long after the use of the contaminated vaccines. There is no documented study around it in Asian countries.

\subsubsection{Genetic factors and family history}

Family history and genetic factors increase risk of NHL in people whose relatives previously were diagnosed with NHL, but hereditary factors are hypothesized to account only for a small percentage of NHL and are unlikely to explain the increase in NHL incidence. Tumor suppressor genes, oncogenes and DNA repair genes may play a role in NHL carcinogenesis, and some genes may interact with environmental exposures that affect NHL risk (Fisher \& Fisher, 2004). In a US multicenter case-control study, Chatterjee et. al showed (Chatterjee, et al., 2004) the strongest associations were found among siblings ( $\mathrm{HR}=7.6,95 \% \mathrm{CI}: 0.98-58.8$ ) and male relatives $(\mathrm{HR}=6.2,95 \% \mathrm{CI}: 0.77-50.0)$ of NHL cases. For a parental history of histopathologically concordant lymphoma, the strongest associations with lymphoma risk among offspring were found for B-cell lymphoma (SIR $=11.8,95 \% \mathrm{CI}$ : 2.2-34.8) and follicular lymphoma (SIR $=6.1,95 \%$ CI: 1.1-18.0) (Altieri, Bermejo, E Hemminki, 2005).

Several genetic polymorphisms associated with the risk of NHL suggest that single nucleotide polymorphisms (SNPs) in tumor necrosis factor (TNF) and interleukin-10 (IL10) are associated with risk of NHL, especially diffuse large B -cell lymphoma. Relatively few studies have examined the potential interaction between germline susceptibility and environmental or lifestyle factors in the etiology of NHL (Alexander, et al., 2007). The mechanism (s) by which genetic predisposition or gene-environment interactions may enhance or reduce the risk of developing NHL remains a largely unexplored area of research (Alexander, et al., 2007).

\subsubsection{Lifestyle and personal and environmental factors}

Results from studies that evaluated lifestyle and personal factors are generally inconsistent, with few exceptions. Alcohol consumption appears to be inversely associated with NHL, based primarily on results from case-control studies (Chiu, et al., 1999; Chiu, et al., 2002). Further evidences from cohort studies are needed. Smoking does not appear to play an important role in the etiology of NHL overall; however, it has relation with follicular lymphoma (Bracci \& Holly, 2005). Fish intake has been associated consistently with a nonsignificantly decreased risk of NHL in several studies (Zhang, et al., 1999), but intake of 
omega-3 fatty acids from fish was not associated with reduced risk of NHL in one cohort study (Purdue, Bassani, Klar, Sloan, \& Kreiger, 2004). Several but not all studies have reported positive association with red meat intake. Data are limited, and results have not been consistent, for estimates of associations with specific types of red meat or with preparation or cooking methods (Chang, et al., 2006; Ward, et al., 1994). Saturated fat intake was associated positively (Chang, et al., 2006), however vegetable consumption was associated inversely, with NHL risk in most studies (Chang, et al., 2005; Mozaheb \& Aledawood, 2011). Biological mechanisms for these dietary factors have not been established. Neither obesity nor physical activity has been associated consistently with NHL (Alexander, et al., 2007).

Certain workers have a slightly increased risk of developing NHL, including farmers; pesticide applicator; miller; meat worker; wood and forestry worker; chemists; painters; mechanics; printers; and worker in the petroleum, rubber, plastics, and synthetics industries (Alexander, et al., 2007). Some of these occupations are more common in Asian countries such as farmers, pesticide applicator, wood worker, worker in petroleum; on the other hand exposure is more because of low educational program in these places. Also There is significant relationship between hair dye use and NHL risk (Altekruse, Jane Henley, \& Thun, 1999).

\section{Hodgkin's Lymphoma}

Hodgkin lymphoma is a neoplastic disease of the lymphoid tissue characterized by the present of multinucleated giant cell of B-cell origin, known as Red-Stenberg cell, in background of numerous reactive lymphocyte (Classical, 2009). HL is less common in Asians, especially at the young adult ages. There is incidence variation by age, social class, geographic location in HL. Thus, the comparison of HL rates in Asian and western countries could inform the relative importance of environmental factors and genetic to disease etiology.

\subsection{Descriptive epidemiology}

The epidemiology of Hodgkin's lymphoma is complex. Hodgkin Lymphoma demonstrates different histologic findings, clinical presentation, and outcome. Hodgkin's lymphoma is relatively uncommon, but at young adult ages it is one of the most common malignancies. Increasingly there is a great difference in incidence between developing and western developed countries. In developing countries, the disorder appear predominantly during childhood and its incidence decreases with age (Thomas, Re, Zander, Wolf, \& Diehl, 2002). The annual age adjusted incidence rates of 2.8 and 2.4 per 100,000 in the USA and UK respectively (RiesLAG, HankeyBF, \& HarrasA, 1994).

Hodgkin's lymphoma has been reported to be rare in Asians. One study in the US from 2000 to 2007, 16,710 cases of HL reported that black and Asians had low incidence (black/white incidence rate ratio (IRR) 0.86, $\mathrm{P}<0.01$; Asian/White IRR 0.43, $\mathrm{P}<0.01$ ). The bimodal pattern of incidence was less prominent for black males. Asian and black presented at a mean age of 38 years compared to 42 years for Whites $(\mathrm{P}<.001)$ (Pareen, Alison, Neha, \& Christopher, 2010).There are few studies in exploring the relative contributions of environmental and hereditary etiology of Hodgkin's lymphoma, and individual risk factors in an Asian population. The other study which compared HL incidence rate in Japanese, Chinese, 
Filipino, and Asian Indian in the US and in Asia reports HL incidence rates were quite low in all Asian subgroups but approximately double in US Asian. The consistently low rates of $\mathrm{HL}$ in Asians suggest genetic resistance to the disease development, possibly associated with HLA type. In addition environmental and lifestyle differences between the USA and Asia are important. In some study from Eastern Asia and among Chinese immigrants in North America indicate increasing incidence trends for HL being associated with westernization (Caporaso, Goldin, Anderson, \& Landgren, 2009). International and interethnic differences and risk factor patterns in case-control data, implicate environmental influences in the etiology of HL (Glaser \& Hsu, 2002).

Incidence rate of HL are usually grater in male than in female (Correa \& O'Conor, 1971). In western countries the young adult peak largely consist of nodular sclerosis tumors, whereas the rise at older ages are largely mixed cellularity and lymphocytic-depleted histology (Spitz, et al., 1986). Hodgkin's lymphoma tends to be more common in young adult with higher socio-economic classes (Correa \& O'Conor, 1971). Pattern of low social class determinants in children and older adult with HL, the age groups at risk for mixed cellularity (MC), support involvement of underling infectious agent given intense exposure, and EBV is a likely candidate based on its high prevalence in these groups (Glaser \& Jarrett, 1996). Based on different studies the most common subtype of HL in the most Asian countries such as Iran, Korea, Thailand, Japan is mixed cellularity and relative paucity of NS subtype, particularly in males (Glaser \& Hsu, 2002), which seems to be related to the etiologic factors (environment and/or inheritance) of disease. Subtypes of HL in different countries are showed in table 4.

\begin{tabular}{|c|c|c|c|c|c|c|c|}
\hline HL & $\begin{array}{c}\text { Iran } \\
\text { No (\%) }\end{array}$ & $\begin{array}{c}\text { Korea } \\
\text { No (\%) }\end{array}$ & $\begin{array}{c}\text { Thailand } \\
\text { No (\%) }\end{array}$ & Taiwan & $\begin{array}{c}\text { Japans } \\
\text { No (\%) }\end{array}$ & $\begin{array}{c}\text { US } \\
\%\end{array}$ & $\begin{array}{c}\text { UK } \\
\%\end{array}$ \\
\hline NS & $10(31.2)$ & $26(31.7)$ & $58(36.9)$ & $29(69)$ & $70(42.4)$ & Up to 08 & 60 \\
\hline MC & $16(50)$ & $38(46.3)$ & $64(40.8)$ & $2(4.7)$ & $51(31)$ & $<10$ & 15 \\
\hline LD & $3(9.3)$ & $6(7.3)$ & $14(8.9)$ & 0 & $8(5)$ & 1 & rare \\
\hline LP & $1(3.1)$ & $4(2.6)$ & $18(11.5)$ & $2(4.7)$ & $18(11)$ & 6 & 10 \\
\hline NLPHD & $2(6.3)$ & $8(9.8)$ & $3(1.9)$ & $3(7.1)$ & $8(5)$ & 5 & 5 \\
\hline
\end{tabular}

Table 4. Subtypes of Hodgkin's disease in various countries

A shift from MC-dominant histologic subtype of HL was observed over 20-year period within Japan, particularly in young adults (Aozasa, Ueda, Tamai, \& Tsujimura, 1986). As NS and MC have been shown to have different environmental cofactors, including socioeconomic status and degree of $E B V$ tumor-cell presence, geographic variation in HL is likely to reflect change in socioeconomically determined exposures whenever possible.

\subsection{Etiologic epidemiology}

The differences in descriptive epidemiology of Hodgkin's lymphoma between children, young adults and older adults may reflect differences in etiology between these age groups.

\subsubsection{Environment}

Infections. Systemic analysis of epidemiological data pointed towards an infectious agent as a potential cause for Hodgkin's lymphoma. Recognition of an association of infectious 
mononucleosis with Hodgkin's disease predate the discovery of EBV (Richard F. Ambinder, 2007). Investigators have reported that EBV infectious mononucleosis is associated with a lifelong "immunologic scar" (Sauce, et al., 2007). The statistical analysis suggested that HL tended to occur 2.9 years after infectious mononucleosis (R.F. Ambinder, 2007). Remarkably, the change in lymphocyte cell population is sustained over years or longer (Richard F. Ambinder, 2007). There are new insights into infectious mononucleosis and disturbances in cellular immunity, new insight relating to the role that viruses may play in molecular pathogenesis of HL, an emerging appreciation of the increased incidence of HL in HIV and its relationship to immune suppression (Richard F. Ambinder, 2007). A role for suppression $\mathrm{T}$ cell suggested in the 1970s, and increasing evidence shows a role for this cells in suppressing antitumor immune responses (Hjalgrim, et al., 2007).

In western countries, about $50 \%$ of all cases of classical HL are $E B V$ positive, means the virus is carried within the tumor cells. Detection of $E B V$ in tumors in these region are least common in young adult disease. In some parts of Latin America, Africa, and Asia, the percentage is much higher with the percentage in children approaching 90-100\% (Glaser, et al., 1997; Zarate Osorno, Roman, Kingma, Meneses Garcia, \& Jaffe, 1995). The MC subtype harboring EBV DNA in up to $70 \%$ of cases and the NS subtype being positive in $15-30 \%$ of cases (Brousset, et al., 1991). Also detection of EBV in HL in most Asian countries are less in young adults and are more detectable in children and older ages. Because of these differences infectious cofactors other than $E B V$ have been suggested, but no consensus in support of any other particular association have emerge (Wilson, et al., 2007).

As we mentioned $E B V$ induce immune suppression, and in an $E B V$ positive person, $M C$ subtype is more common (like HIV positive), therefore in MC subtype of HL, which is more common in Asian countries, immunodeficiency has more important role in comparison with other subtypes.

HIV. Hodgkin's lymphoma in the setting of $H I V$ has distinctive features and is usually associated with EBV infection (Glaser, et al., 2003). HL in patients with HIV tends to present at an advanced stage with associated B symptoms and extra-nodal involvement and is most often a mixed cellularity subtype. Model fitting suggested that for persons with AIDS with moderate immunosuppretion at the onset of AIDS, HL risk was 15-fold higher than in the general population. Lower CD4 counts were associated with less risk, the risk fall as CD4 count fall (R.F. Ambinder, 2007).

\subsubsection{Inheritance}

The risk of developing HL among family member of patients affected by HL increase from three-to nine-fold (Haim, Cohen, \& Robinson, 1982). One study showed a significant association between HL and parental consanguinity and pointed to the possible etiologic role of recessive inheritance (Abramson, Pridan, Sacks, Avitzour, \& Peritz, 1978).

The relative risk for HL among first degree relatives of cases compared with controls was 3.1. Relative risks were higher in males compared with females, and in siblings of cases compared with parents and offspring. Identifying inherited susceptibility genes is an important step towards defining the pathway leading to development of HL and 
understanding its etiology. There are many studies of somatic mutations in HL tumor cells, but although there are associations with HLA types, specific germline genes causing susceptibility have not yet been identified. On the other hand it is not known whether or how extrinsic risk factors interact with genetic susceptibility (Goldin, et al., 2005).

Oza et al. in the single study of HL-HLA relationship found that HLA-DPB1*0301 inreased risk of HL in all ethnic groups, while HLA-DPB1*0401 was associated with a lowered risk of HL in Japanese and Chinese and an elevated risk for US whites and Israelis (Oza, et al., 1994). Therefore; HLA-DPB1*1401, or factors related to it, could explain some of the lower incidence of $\mathrm{HL}$ in certain Asian ethnic groups, although environmental factors involves as well and indicate that HL etiology is complex.

\section{Conclusion}

There is evidence of etiologic heterogeneity among types of NHL, with different incidence patterns according to age, sex, race and specially geography. The extent to which these differences reflect differences in etiology needs further study.

Epidemiologic studies indicate that environmental factors may play an important role in the etiology of non-Hodgkin's lymphoma. Given the recognition that transmissible agents, especially in the developing world, are a significant cause of some kind of lymphoma, focusing on effective strategies to prevent infection altogether will go a long way to diminish the lymphoma. Additionally, effective strategies for toxic and occupational exposure and changing global lifestyles will yield huge dividends. Future epidemiologic research on NHL will be enhanced by analyses of subtypes of NHL, improved reliability and validity of exposure assessment tools to evaluate occupational, environmental and personal exposures, and evaluation of susceptible subgroups of individuals whose risk of NHL may differ from that of the general population. Finding the relation between environmental factors and genes in lymphomagenesis also important and it needs more investigation.

Lower rate of HL in Asians suggestive of genetic resistance, in addition international and inter-ethnic differences implicate environmental influence. Additional insight into the balance of genetic and environment factors on HL risk should be forthcoming. Differences in HL risk reported in several studies indicate that such studies of HL risk factors should be conducted for specific Asian population.

Overall in developing countries the most common subtype of lymphoid malignancies both HL and NHL are those subtype which immunodeficiency have an important role in their pathogenesis.

\section{References}

Abbaszadegan, M. R., Gholamin, M., Tabatabaee, A., Farid, R., Houshmand, M., \& Abbaszadegan, M. (2003). Prevalence of human T-lymphotropic virus type 1 among blood donors from Mashhad, Iran. Journal of clinical microbiology, 41 (6), 2593, ISSN 0095-1137.

Ablashi, D., Chatlynne, L., Cooper, H., Thomas, D., Yadav, M., Norhanom, A., et al. (1999). Seroprevalence of human herpesvirus-8 (HHV-8) in countries of Southeast Asia 
compared to the USA, the Caribbean and Africa. British journal of cancer, 81 (5), 893, ISSN 0007-0920.

Abramson, J., Pridan, H., Sacks, M., Avitzour, M., \& Peritz, E. (1978). A case-control study of Hodgkin's disease in Israel. Journal of the National Cancer Institute, 61 (2), 307, ISSN 0027-8874.

Advani, S. H., Banavali, S. D., Agarwala, S., Gopal, R., Dinshaw, K. A., Borges, A., et al. (1990). The pattern of malignant lymphoma in India: a study of 1371 cases. Leukemia and Lymphoma, 2 (5), 307-316, ISSN 1042-8194.

Alexander, D. D., Mink, P. J., Adami, H. O., Chang, E. T., Cole, P., Mandel, J. S., et al. (2007). The non Hodgkin lymphomas: A review of the epidemiologic literature. International journal of cancer, 120 (S12), 1-390, ISSN 020-7136.

Altekruse, S. F., Jane Henley, S., \& Thun, M. J. (1999). Deaths from hematopoietic and other cancers in relation to permanent hair dye use in a large prospective study (United States). Cancer Causes and Control, 10 (6), 617-625, ISSN 0957-5243.

Altieri, A., Bermejo, J. L., \& Hemminki, K. (2005). Familial risk for non-Hodgkin lymphoma and other lymphoproliferative malignancies by histopathologic subtype: the Swedish Family-Cancer Database. Blood, 106 (2), 668, ISSN 0006-4971.

Ambinder, R. F. (2007). Epstein-Barr Virus and Hodgkin Lymphoma. Hematology, 2007 (1), 204-209, ISSN 1024-5332.

Anderson, J. R., Armitage, J. O., \& Weisenburger, D. D. (1998). Epidemiology of the nonHodgkin's lymphomas: Distributions of the major subtypes differ by geographic locations. Annals of Oncology, 9 (7), 717, ISSN 0923-7534.

Aoki, R., Karube, K., Sugita, Y., Nomura, Y., Shimizu, K., Kimura, Y., et al. (2008). Distribution of malignant lymphoma in Japan: analysis of 2260 cases, 2001-2006. Pathology International, 58 (3), 174-182, ISSN 1320-5463.

Aozasa, K., Tsujimoto, M., Sakurai, M., Honda, M., Yamashita, K., Hanada, M., et al. (1985). Non-Hodgkin's lymphomas in Osaka, Japan. European Journal of Cancer and Clinical Oncology, 21 (4), 487-492, ISSN 0959-8049.

Aozasa, K., Ueda, T., Tamai, M., \& Tsujimura, T. (1986). Hodgkin's disease in Osaka, Japan (1964-1985). European Journal of Cancer and Clinical Oncology, 22 (9), 1117-1119, ISSN 0959-8049.

Arellano, F. M., Arana, A., Wentworth, C. E., Fernández-Vidaurre, C., Schlienger, R. G., \& Conde, E. (2009). Lymphoma among patients with atopic dermatitis and/or treated with topical immunosuppressants in the United Kingdom. Journal of Allergy and Clinical Immunology, 123 (5), 1111-1116. e1113, ISSN 0091-6749.

Armstrong, G. L., Wasley, A., Simard, E. P., McQuillan, G. M., Kuhnert, W. L., \& Alter, M. J. (2006). The prevalence of hepatitis C virus infection in the United States, 1999 through 2002. Annals of Internal Medicine, 144 (10), 705, ISSN 00034819.

Ascoli, V., Lo Coco, F., Torelli, G., Vallisa, D., Cavanna, L., Bergonzi, C., et al. (2002). Human herpesvirus 8-associated primary effusion lymphoma in HIV--patients: a clinicopidemiologic variant resembling classic Kaposi's sarcoma. haematologica, 87 (4), 339, 0390-6078. 
Atichartakarn, V., Kurathong, S., Nitiyanand, P., Kiatikajornthada, N., Petchclai, B., Ou, D., et al. (1982). Alpha chain disease in the Thai man. The Southeast Asian journal of tropical medicine and public health, 13 (1), 120.

Au, W. Y., Ma, S. Y., Chim, C. S., Choy, C., Loong, F., Lie, A., et al. (2005). Clinicopathologic features and treatment outcome of mature T-cell and natural killer-cell lymphomas diagnosed according to the World Health Organization classification scheme: a single center experience of 10 years. Annals of Oncology, 16 (2), 206, ISSN 09237534.

Azar, H. A. (1962). Cancer in Lebanon and the near east. Cancer, 15 (1), 66-78, ISSN $1097-$ 0142.

Baris, D., \& Zahm, S. H. (2000). Epidemiology of lymphomas. Current Opinion in Oncology, 12 (5), 383-394, ISSN 1040-8746.

Biagi, J. J., \& Seymour, J. F. (2002). Insights into the molecular pathogenesis of follicular lymphoma arising from analysis of geographic variation. Blood, 99 (12), 4265, ISSN 0006-4971.

Biggar, R. J., \& Rabkin, C. S. (1992). The epidemiology of acquired immunodeficiency syndrome-related lymphomas. Current Opinion in Oncology, 4 (5), 883, ISSN 10408746.

Boot, H., \& Jong, D. (2002). Gastric lymphoma: the revolution of the past decade. Scandinavian Journal of Gastroenterology, 37 (230), 27-36, ISSN 0036-5521.

Bracci, P. M., \& Holly, E. A. (2005). Tobacco use and non-Hodgkin lymphoma: results from a population-based case-control study in the San Francisco Bay Area, California. Cancer Causes and Control, 16 (4), 333-346, ISSN 0957-5243.

Brousset, P., Chittal, S., Schlaifer, D., Icart, J., Payen, C., Rigal-Huguet, F., et al. (1991). Detection of Epstein-Barr virus messenger RNA in Reed-Sternberg cells of Hodgkin's disease by in situ hybridization with biotinylated probes on specially processed modified acetone methyl benzoate xylene (ModAMeX) sections [see comments]. Blood, 77 (8), 1781, ISSN 0006-4971.

Caporaso, N. E., Goldin, L. R., Anderson, W. F., \& Landgren, O. (2009). Current insight on trends, causes, and mechanisms of Hodgkin's lymphoma. The Cancer Journal, 15 (2), 117, ISSN 0340-7004.

Chang, E. T., Bälter, K. M., Torrång, A., Smedby, K. E., Melbye, M., Sundström, C., et al. (2006). Nutrient intake and risk of non-Hodgkin's lymphoma. American journal of epidemiology, 164 (12), 1222, ISSN 0002-9173.

Chang, E. T., Ekström Smedby, K., Zhang, S. M., Hjalgrim, H., Melbye, M., Öst, Å., et al. (2005). Dietary factors and risk of non-Hodgkin lymphoma in men and women. Cancer Epidemiology Biomarkers \& Prevention, 14 (2), 512, ISSN 1055-9965.

Chatterjee, N., Hartge, P., Cerhan, J. R., Cozen, W., Davis, S., Ishibe, N., et al. (2004). Risk of non-Hodgkin's lymphoma and family history of lymphatic, hematologic, and other cancers. Cancer Epidemiology Biomarkers \& Prevention, 13 (9), 1415, ISSN 10559965.

Chiu, B. C. H., Cerhan, J., Gapstur, S., Sellers, T., Zheng, W., Lutz, C., et al. (1999). Alcohol consumption and non-Hodgkin lymphoma in a cohort of older women. British journal of cancer, 80 (9), 1476, ISSN 0007-0963. 
Chiu, B. C. H., \& Weisenburger, D. D. (2003). An update of the epidemiology of non-Hodgkin's lymphoma. Clinical Lymphoma, Myeloma \& Leukemia, 4 (3), 161168.

Chiu, B. C. H., Weisenburger, D. D., Cantor, K. P., Zahm, S. H., Holmes, F., Burmeister, L. F., et al. (2002). Alcohol consumption, family history of hematolymphoproliferative cancer, and the risk of non-Hodgkin's lymphoma in men. Annals of epidemiology, 12 (5), 309-315, ISSN 0007-0963.

Classical, H. (2009). Michael Craig, Jame Abraham, Wyndham H. Wilson, and Elaine S. Jaffe. Bethesda Handbook of Clinical Hematology, 184.

Correa, P., \& O'Conor, G. T. (1971). Epidemiologic patterns of Hodgkin's disease. International journal of cancer, 8 (2), 192-201, ISSN 0020-7128.

Coté, T. R., Biggar, R. J., Rosenberg, P. S., Devesa, S. S., Percy, C., Yellin, F. J., et al. (1997). Non Hodgkin's lymphoma among people with AIDS: Incidence, presentation and public health burden. International journal of cancer, 73 (5), 645-650, ISSN 00207128.

Coutinho, R. (2000). Highly active antiretroviral therapy and incidence of cancer in human immunodeficiency virus-infected adults. J NATL CANCER I, 92 (15), 1823-1830, ISSN 0027-8874.

Cummins, A. G., \& Roberts Thomson, I. C. (2009). Prevalence of celiac disease in the AsiaPacific region. Journal of Gastroenterology and Hepatology, 24 (8), 1347-1351, ISSN 0815-9319.

d'Amore, F., Christensen, B. E., Brincker, H., Pedersen, N. T., Thorling, K., Hastrup, J., et al. (1991). Clinicopathological features and prognostic factors in extranodal nonHodgkin lymphomas. European Journal of Cancer and Clinical Oncology, 27 (10), 12011208, ISSN, 0959-8049.

De Sanjose, S., Benavente, Y., Vajdic, C. M., Engels, E. A., Morton, L. M., Bracci, P. M., et al. (2008). Hepatitis C and non-Hodgkin lymphoma among 4784 cases and 6269 controls from the International Lymphoma Epidemiology Consortium. Clinical Gastroenterology and Hepatology, 6 (4), 451-458, ISSN 1542-3565.

De Thé, G., \& Bomford, R. (1993). An HTLV-I vaccine: why, how, for whom? AIDS research and human retroviruses, 9 (5), 381-386, ISSN 0889-2229.

Devesa, S. S., \& Fears, T. (1992). Non-Hodgkin's Lymphoma Time Trends: United States and International Data. Cancer Research, 52 (19 Supplement), 5432s-5440s, ISSN 00085472.

Dhir, A. A., Sawant, S., Dikshit, R. P., Parikh, P., Srivastava, S., Badwe, R., et al. (2008). Spectrum of HIV/AIDS related cancers in India. Cancer Causes and Control, 19 (2), 147-153, ISSN 0957-5243.

$\mathrm{Du}, \mathrm{M}$. Q. (2007). MALT lymphoma: recent advances in aetiology and molecular genetics. Journal of Clinical and Experimental Hematopathology, 47 (2), 31-42, ISSN .

Dutcher, J. P. (2003). The role of Epstein-Barr virus and elevated levels of tumor necrosis factor in determining prognosis in Asian peripheral T-cell lymphomas. Leukemia Research, 27 (6), 467-469, ISSN 0145-2126.

Ekström-Smedby, K. (2006). Epidemiology and etiology of non-Hodgkin lymphoma - a review. Acta Oncologica, 45 (3), 258-271, ISSN 0284-186X . 
Ekström, K., Hjalgrim, H., Brandt, L., Baecklund, E., Klareskog, L., Ekbom, A., et al. (2003). Risk of malignant lymphomas in patients with rheumatoid arthritis and in their first degree relatives. Arthritis \& Rheumatism, 48 (4), 963-970.

Evans, A. S., \& Kaslow, R. A. (1997). Viral infections of humans: epidemiology and control: Springer Us, ISBN-13:978-0306448560.

Farinha, P., \& Gascoyne, R. D. (2005). Helicobacter pylori and MALT lymphoma. Editorial board A4, 128, 1579-1605.

Feuillard, J., Aubin, J. T., Poirel, L., Davi, F., Kujas, M., Rousselet, M. C., et al. (1997). Detection rate and intratumoral virus load of human herpesvirus 8 in immunodeficiency related B cell lymphoid malignancies. Journal of medical virology, 53 (3), 277-281, ISSN 0146-6615.

Filipovich, A., Mathur, A., Kamat, D., \& Shapiro, R. (1992). Primary immunodeficiencies: genetic risk factors for lymphoma. Cancer Research, 52 (19 Supplement), 5465s, ISSN 0939-5213.

Fisher, S. G., \& Fisher, R. I. (2004). The epidemiology of non-Hodgkin's lymphoma. Oncogene, 23 (38), 6524-6534, ISSN 6524-6534.

Foss, F. M., Zinzani, P. L., Vose, J. M., Gascoyne, R. D., Rosen, S. T., \& Tobinai, K. (2011). Peripheral T-cell lymphoma. Blood, 117 (25), 6756, ISSN 0006-4971.

Freeman, C., Berg, J. W., \& Cutler, S. J. (1972). Occurrence and prognosis of extranodal lymphomas. Cancer, 29 (1), 252-260, ISSN 1097-0142.

Frimpong-Boateng, K. Infectious Disease and Cancer in Africa-A medical and Demographical Reality.

Gaidano, G., Pastore, C., Gloghini, A., Volpe, G., Ghia, P., Saglio, G., et al. (1996). AIDSrelated non-Hodgkin's lymphomas: molecular genetics, viral infection and cytokine deregulation. Acta haematologica, 95 (3-4), 193-198, ISSN 0001-5792.

Gessain, A., Gallo, R. C., \& Franchini, G. (1992). Low degree of human T-cell leukemia/lymphoma virus type I genetic drift in vivo as a means of monitoring viral transmission and movement of ancient human populations. Journal of virology, 66 (4), 2288, ISSN 0022-838X.

Glaser, S. L., Clarke, C. A., Gulley, M. L., Craig, F. E., DiGiuseppe, J. A., Dorfman, R. F., et al. (2003). Population based patterns of human immunodeficiency virus related Hodgkin lymphoma in the Greater San Francisco Bay Area, 1988-1998. Cancer, 98 (2), 300-309, ISSN 1097-0142.

Glaser, S. L., \& Hsu, J. L. (2002). Hodgkin's disease in Asians: incidence patterns and risk factors in population-based data. Leukemia Research, 26 (3), 261-269, ISSN 01352126.

Glaser, S. L., \& Jarrett, R. F. (1996). 1 The epidemiology of Hodgkin's disease. Baillière's clinical haematology, 9 (3), 401-416, ISSN 1521-6926.

Glaser, S. L., Lin, R. J., Stewart, S. L., Ambinder, R. F., Jarrett, R. F., Brousset, P., et al. (1997). Epstein Barr virus associated Hodgkin's disease: epidemiologic characteristics in international data. International journal of cancer, 70 (4), 375-382, ISSN 00207136.

Goedert, J. J., Coté, T. R., Virgo, P., Scoppa, S. M., Kingma, D. W., Gail, M. H., et al. (1998). Spectrum of AIDS-associated malignant disorders. The Lancet, 351 (9119), 18331839, ISSN 0140-6736. 
Goldin, L., McMaster, M., Ter-Minassian, M., Saddlemire, S., Harmsen, B., Lalonde, G., et al. (2005). A genome screen of families at high risk for Hodgkin lymphoma: evidence for a susceptibility gene on chromosome 4. Journal of medical genetics, 42 (7), 595, ISSN 0022-2593.

Goncalves, D. U., Proietti, F. A., Ribas, J. G. R., Araujo, M. G., Pinheiro, S. R., Guedes, A. C., et al. (2010). Epidemiology, treatment, and prevention of human T-cell leukemia virus type 1-associated diseases. Clinical Microbiology Reviews, 23 (3), 577, ISSN 0893-8512.

Groves, F. D., Linet, M. S., Travis, L. B., \& Devesa, S. S. (2000). Cancer surveillance series: non-Hodgkin's lymphoma incidence by histologic subtype in the United States from 1978 through 1995. Journal of the National Cancer Institute, 92 (15), 1240, ISSN 0027-8874.

Grulich, A. E., Li, Y., McDonald, A. M., Correll, P. K., Law, M. G., \& Kaldor, J. M. (2001). Decreasing rates of Kaposi's sarcoma and non-Hodgkin's lymphoma in the era of potent combination anti-retroviral therapy. Aids, 15 (5), 629, ISSN 02699370.

Haim, N., Cohen, Y., \& Robinson, E. (1982). Malignant Lymphoma in First Degree Blood Relatives. Cancer, 49 (10), 2197-2200, ISSN 1097-0142.

Heller, K., Steinherz, P., Portlock, C., \& Munz, C. (2007). EBV-positive lymphoma patients have a selective deficiency in EBV immunity. Journal of Clinical Oncology, 25 (18_suppl), 21032, ISSN 0732-183X.

Hermine, O., Lefrère, F., Bronowicki, J. P., Mariette, X., Jondeau, K., Eclache-Saudreau, V., et al. (2002). Regression of splenic lymphoma with villous lymphocytes after treatment of hepatitis C virus infection. New England Journal of Medicine, 347 (2), 8994.

Hinuma, Y., Nagata, K., Hanaoka, M., Nakai, M., Matsumoto, T., Kinoshita, K. I., et al. (1981). Adult T-cell leukemia: antigen in an ATL cell line and detection of antibodies to the antigen in human sera. Proceedings of the National Academy of Sciences, 78 (10), 6476.

Hirata, M., Hayashi, J., Noguchi, A., Nakashima, K., Kajiyama, W., Kashiwagi, S., et al. (1992). The effects of breastfeeding and presence of antibody to p40tax protein of human $\mathrm{T}$ cell lymphotropic virus type-I on mother to child transmission. International journal of epidemiology, 21 (5), 989, ISSN 03005771.

Hishima, T., Oyaizu, N., Fujii, T., Tachikawa, N., Ajisawa, A., Negishi, M., et al. (2006). Decrease in Epstein-Barr virus-positive AIDS-related lymphoma in the era of highly active antiretroviral therapy. Microbes and infection, 8 (5), 1301-1307, ISSN 1286-4576.

Hjalgrim, H., Ekström Smedby, K., Rostgaard, K., Molin, D., Hamilton-Dutoit, S., Chang, E. T., et al. (2007). Infectious mononucleosis, childhood social environment, and risk of Hodgkin lymphoma. Cancer Research, 67 (5), 2382, ISSN 0008-543X.

Ho, F., Todd, D., Loke, S., Ng, R., \& Khoo, R. (1984). Clinico pathological features of malignant lymphomas in 294 Hong Kong Chinese patients, retrospective study covering an eight year period. International journal of cancer, 34 (2), 143-148, ISSN 0020-7136. 
Hooper, W. C., Holman, R. C., Clarke, M., \& Chorba, T. L. (2001). Trends in non hodgkin lymphoma (NHL) and HIV associated NHL deaths in the United States. American journal of hematology, 66 (3), 159-166, ISSN 0361-8609.

Hunt, K. E., \& Reichard, K. K. (2008). Diffuse large B-cell lymphoma. Archives of pathology $\mathcal{E}$ laboratory medicine, 132 (1), 118-124, ISSN 0003-9969.

Hunt, R., Sumanac, K., \& Huang, J. Q. (2001). Review article: should we kill or should we save Helicobacter pylori? Alimentary pharmacology \& therapeutics, 15, 51-59, ISSN 0269-2813.

Imperiale, M. J. (2000). The human polyomaviruses, BKV and JCV: molecular pathogenesis of acute disease and potential role in cancer. Virology (New York), 267 (1), 1-7, ISSN 0042-6822.

Intragumtornchai, T., Wannakrairoj, P., Chaimongkol, B., Bhoopat, L., Lekhakula, A., Thamprasit, T., et al. (1996). Non Hodgkin's lymphomas in Thailand: A retrospective pathologic and clinical analysis of 1391 cases. Cancer, 78 (8), 18131819, ISSN 1097-0142.

Izumo, T. (1996). Malignant lymphoma in Japanese HTLV1-non endemic area based on the REAL classification. Ann. Oncol., 7 (3), 342, ISSN 0923-7534.

Jaffe, E. S. (1999). Hematopathology: integration of morphologic features and biologic markers for diagnosis. Modern pathology: an official journal of the United States and Canadian Academy of Pathology, Inc, 12 (2), 109, ISSN 0893-3952.

Jaffe, E. S., Chan, J. K. C., Su, I. J., Frizzera, G., Mori, S., Feller, A., et al. (1996). Report of the workshop on nasal and related extranodal angiocentric $\mathrm{T} /$ natural killer cell lymphomas: definitions, differential diagnosis, and epidemiology. The American journal of surgical pathology, 20 (1), 103, ISSN 0147-5185.

Jafroodi, M., Zargari, O., \& Hoda, S. (2009). Concomitant Hodgkin's Lymphoma and Atopic Dermatitis in a Child with Celiac Disease. Archives of Iranian Medicine, 12 (3), 317319, ISSN 1029-2977.

Kadin, M. E., Berard, C. W., Nanba, K., \& Wakasa, H. (1983). Lymphoproliferative diseases in Japan and Western countries: proceedings of the United States-Japan seminar, september 6 and 7, 1982, in Seattle, Washington= Les affections lymphoprolifératives au Japon et dans les régions occidentales. Comptes-rendus du séminaire Etats-Unis-Japon du 6 au 7 septembre 1982 Seattle, Washington. Human pathology, 14 (9), 745-772, ISSN 0046-8177.

Kakuda, K., Ikematsu, H., Chong, W. L. Y., Hayashi, J., \& Kashiwagi, S. (2002). Molecular epidemiology of human $\mathrm{T}$ lymphotropic virus type 1 transmission in Okinawa, Japan. The American journal of tropical medicine and hygiene, 66 (4), 404, ISSN 00029637.

Kamiyama, K., Kinjo, T., Chinen, K., Iwamasa, T., Uezato, H., Miyagi, J., et al. (2004). Human herpesvirus 8 (HHV8) sequence variations in HHV8 related tumours in Okinawa, a subtropical island in southern Japan. Journal of clinical pathology, 57 (5), 529, ISSN 0021-9746.

Kao, J. H., \& Chen, D. S. (2000). Transmission of hepatitis C virus in Asia: past and present perspectives. Journal of Gastroenterology and Hepatology, 15, E91-E96, ISSN 08159319. 
Khojasteh, A., \& Haghighi, P. (1990). Immunoproliferative small intestinal disease: portrait of a potentially preventable cancer from the Third World. The American journal of medicine, 89 (4), 483-490, ISSN 0002-9343.

Khojasteh, A., Haghshenass, M., \& Haghighi, P. (1983). Immunoproliferative small intestinal disease. New England Journal of Medicine, 308 (23), 1401-1405, ISSN 00283635.

Kim, C. W., Kim, I., Ko, Y. H., Cho, H., Yang, W. I., Kwon, G. Y., et al. (1992). Clinicopathologic and immunophenotypic study of non-Hodgkin's lymphoma in Korea. Lymphoreticular Study Group of the Korean Society of Pathologists. Journal of Korean medical science, 7 (3), 193, ISSN 1011-8934.

King, P., Wilkes, J., \& DIAZ ARIAS, A. (1998). Hepatitis C virus infection in non Hodgkin's lymphoma. Clinical \& Laboratory Haematology, 20 (2), 107-110, ISSN 17515521.

Kinlen, L. (1992). Immunosuppressive therapy and acquired immunological disorders. Cancer Research, 52 (19 Supplement), 5474s, ISSN 0008-5472.

Ko, Y. H., Kim, C. W., Park, C. S., Jang, H. K., Lee, S. S., Kim, S. H., et al. (1998). REAL classification of malignant lymphomas in the Republic of Korea. Cancer, 83 (4), 806812, ISSN 1097-0142.

Ko, Y. H., \& Lee, J. D. (1994). EBV in situ hybridization study for non-Hodgkin's lymphomas. Journal of Korean medical science, 9 (3), 224.

Ko, Y. H., \& Lee, J. D. (1996). Epstein-Barr virus in Korean malignant lymphomas. The Korean Journal of Pathology, 30 (11), 1011-1017.

Lankarani, K., Masoompour, S., Masoompour, M., Malekzadeh, R., Tabei, S., \& Haghshenas, M. (2005). Changing epidemiology of IPSID in Southern Iran. Gut, 54 (2), 311, ISSN 0017-5749.

Lee, M. Y., Tan, T. D., Feng, A. C., \& Liu, M. C. (2005). Clinicopathological analysis of malignant lymphoma in Taiwan, defined according to the World Health Organization classification. haematologica, 90 (12), 1703, ISSN 0390-6078.

Lee, M. Y., Tsou, M. H., Tan, T. D., \& Lu, M. C. (2005). Clinicopathological analysis of T cell lymphoma in Taiwan according to WHO classification: high incidence of enteropathy type intestinal T cell lymphoma. European journal of haematology, 75 (3), 221-226, ISSN 0902-4441.

Li, H. C., Biggar, R. J., Miley, W. J., Maloney, E. M., Cranston, B., Hanchard, B., et al. (2004). Provirus load in breast milk and risk of mother-to-child transmission of human T lymphotropic virus type I. Journal of Infectious Diseases, 190 (7), 1275, ISSN 0022-1899.

LIU, H. F. U., Vandamme, A. M., KAZADI, K., Carton, H., Desmyter, J., \& GOUBAU, P. (1994). Familial transmission and minimal sequence variability of human Tlymphotropic virus type I (HTLV-I) in Zaire. AIDS research and human retroviruses, 10 (9), 1135-1142, ISSN 0889-2229.

Makishima, H., Ito, T., Kodama, R., Asano, N., Nakazawa, H., Akamatsu, T., et al. (2006). Intestinal diffuse large B-cell lymphoma associated with celiac disease: a Japanese case. International journal of hematology, 83 (1), 63-65, ISSN 0925-5710.

Morgan, O. S., Mora, C., Rodgers-Johnson, P., \& Char, G. (1989). HTLV-1 and polymyositis in Jamaica. The Lancet, 334 (8673), 1184-1187, ISSN 0140-2381. 
Morton, L. M., Wang, S. S., Devesa, S. S., Hartge, P., Weisenburger, D. D., \& Linet, M. S. (2006). Lymphoma incidence patterns by WHO subtype in the United States, 19922001. Blood, 107 (1), 265, ISSN 0006-4971.

Mozaheb, Z., Aledavood, A., \& Farzad, F. (2011). Distributions of major sub-types of lymphoid malignancies among adults in Mashhad, Iran. Cancer epidemiology, 35 (1), 26-29, ISSN 1877-7821.

Mozaheb, Z., Aledavood, A. (2011). Diet and non-Hodgkin Lymphoma risk, Proceeding of EHA, $16^{\text {th }}$ Congress of the Europian Hematologic Association, pp s615, ISSN 0390-6078, LONDON,UK, June 9-12, 2011

Mueller, N., Okayama, A., Stuver, S., \& Tachibana, N. (1996). Findings from the Miyazaki cohort study. JAIDS Journal of Acquired Immune Deficiency Syndromes, 13, S2, ISSN $1525-4135$.

Müller, A. M. S., Ihorst, G., Mertelsmann, R., \& Engelhardt, M. (2005). Epidemiology of nonHodgkin's lymphoma (NHL): trends, geographic distribution, and etiology. Annals of Hematology, 84 (1), 1-12.

Naresh, K., Srinivas, V., \& Soman, C. (2000). Distribution of various subtypes of nonHodgkin's lymphoma in India: a study of 2773 lymphomas using REAL and WHO Classifications. Annals of Oncology, 11 (suppl 1), S63, ISSN 0923-7534.

Nerurkar, V. R., Song, K. J., Saitou, N., Melland, R. R., \& Yanagihara, R. (1993). Interfamilial and intrafamilial genomic diversity and molecular phylogeny of human T-cell lymphotropic virus type I from Papua New Guinea and the Solomon Islands. Virology, 196 (2), 506-513, ISSN 0042-6822.

Newton, R., Ferlay, J., Beral, V., \& Devesa, S. S. (1997). The epidemiology of non Hodgkin's lymphoma: Comparison of nodal and extra nodal sites. International journal of cancer, 72 (6), 923-930, ISSN 0020-7128.

Ohshima, K., Suzumiya, J., \& Kikuchi, M. (2002). The World Health Organization classification of malignant lymphoma: Incidence and clinical prognosis in HTLV 1 endemic area of Fukuoka. Pathology International, 52 (1), 1-12, ISSN 13205463.

Oza, A. M., Tonks, S., Lim, J., Fleetwood, M. A., Lister, T. A., Bodmer, J. G., et al. (1994). A clinical and epidemiological study of human leukocyte antigen-DPB alleles in Hodgkin's disease. Cancer Research, 54 (19), 5101, ISSN 0008-5472.

Pareen, S., Alison, M., Neha, M., \& Christopher, R. (2010). Incidence Patterns and Outcomes for Hodgkin Lymphoma Patients in the United States. Advances in Hematology, 2011.

Parkin, D. M., Bray, F., Ferlay, J., \& Pisani, P. (2005). Global Cancer Statistics, 2002. CA: A Cancer Journal for Clinicians, 55 (2), 74-108.

Parsonnet, J., Hansen, S., Rodriguez, L., Gelb, A. B., Warnke, R. A., Jellum, E., et al. (1994a). Helicobacter pylori infection and gastric lymphoma. New England Journal of Medicine, 330 (18), 1267-1271, ISSN 0028-7493.

Pathologists, L. S. G. o. J. (2000). The World Health Organization classification of malignant lymphomas in Japan: incidence of recently recognized entities. Pathol Int, 50, 696702, ISSN 1320-5463. 
Pawson, R., Richardson, D. S., Pagliuca, A., Kelsey, S. M., Hoque, S., Breuer, J., et al. (1998). Adult T-cell leukemia/lymphoma in London: clinical experience of 21 cases. Leukemia E lymphoma, 31 (1-2), 177-185, ISSN 1042-8194.

Poulin, D. L., \& DeCaprio, J. A. (2006). Is there a role for SV40 in human cancer? Journal of Clinical Oncology, 24 (26), 4356, ISSN 0732-183X.

Pounder, R., \& Ng, D. (1995). The prevalence of Helicobacter pylori infection in different countries. Alimentary pharmacology and therapeutics, 9 (2), 33-40, ISSN 02692813.

Pramoolsinsap, C., Kurathong, S., Atichartakarn, V., \& Nitiyanand, P. (1993). Immunoproliferative small intestinal disease (IPSID) in Thailand. The Southeast Asian journal of tropical medicine and public health, 24 (1), 11.

Proietti, F. A., Carneiro-Proietti, A. B. F., Catalan-Soares, B. C., \& Murphy, E. L. (2005). Global epidemiology of HTLV-I infection and associated diseases. Oncogene, 24 (39), 6058-6068, ISSN 0950-9232.

Purdue, M. P., Bassani, D. G., Klar, N. S., Sloan, M., \& Kreiger, N. (2004). Dietary factors and risk of non-Hodgkin lymphoma by histologic subtype: a case-control analysis. Cancer Epidemiology Biomarkers \& Prevention, 13 (10), 1665, ISSN 1055-9965.

Rabkin, C. S., \& Yellin, F. (1994). Cancer incidence in a population with a high prevalence of infection with human immunodeficiency virus type 1. Journal of the National Cancer Institute, 86 (22), 1711, ISSN 0027-3864.

Ragni, M. V., Belle, S. H., Jaffe, R. A., Duerstein, S. L., Bass, D. C., McMillan, C. W., et al. (1993). Acquired immunodeficiency syndrome-associated non-Hodgkin's lymphomas and other malignancies in patients with hemophilia. Blood, 81 (7), 1889, ISSN 0006-4971.

RiesLAG, M. B. A., HankeyBF, K. C. L., \& HarrasA, E. B. K. (1994). SEER cancer statistics review, 1973-1991: tables and graphs. Bethesda (MD): National Institutes of Health, National Cancer Institute.

Saadoun, D., Landau, D., Calabrese, L., \& Cacoub, P. (2007). Hepatitis C-associated mixed cryoglobulinaemia: a crossroad between autoimmunity and lymphoproliferation. Rheumatology, 46 (8), 1234, ISSN 1462-0324.

Salem, P., Anaissie, E., Allam, C., Geha, S., Hashimi, L., Ibrahim, N., et al. (1986). Non Hodgkin's lymphomas in the Middle East. A study of 417 patients with emphasis on special features. Cancer, 58 (5), 1162-1166, ISSN 1097-0142.

Salem, P. A., \& Estephan, F. F. (2005). Immunoproliferative small intestinal disease: Current concepts. The Cancer Journal, 11 (5), 374, ISSN 1097-0142.

Sauce, D., Larsen, M., Leese, A., Millar, D., Khan, N., Hislop, A., et al. (2007). IL 7R versus CCR7 and CD45 as Markers of Virus Specific CD8+ T Cell Differentiation: Contrasting Pictures in Blood and Tonsillar Lymphoid Tissue. Journal of Infectious Diseases, 195 (2), 268, ISSN 0022-1899.

Seow, A., \& Registry, S. C. (2004). Trends in cancer incidence in Singapore, 1968-2002: Singapore Cancer Registry.

Serraino, D., Piselli, P., Angeletti, C., Scuderi, M., Ippolito, G., \& Capobianchi, M. (2005). Infection with Epstein-Barr virus and cancer: an epidemiological review. Journal of biological regulators and homeostatic agents, 19 (1-2), 63-70, ISSN 0393974X. 
Shih, L., \& Liang, D. (1991). Non-Hodgkin's lymphomas in Asia. Hematology/oncology clinics of North America, 5 (5), 983, ISSN 0889-8588.

Shimoyama, M. (1991). Diagnostic criteria and classification of clinical subtypes of adult T cell leukaemia lymphoma. British Journal of Haematology, 79 (3), 428-437, ISSN 00071048.

Smedby KE, Hjalgrim H. (2011). Epidemiology and etiology of mantle cell lymphoma and other non-Hodgkin lymphoma subtype. Semin Cancer Biol,21 (5),293-298, ISSN 1044-579X.

Smith, A., Roman, E., Howell, D., Jones, R., Patmore, R., Jack, A., et al. (2010). The Haematological Malignancy Research Network (HMRN): a new information strategy for population based epidemiology and health service research. British Journal of Haematology, 148 (5), 739-753, ISSN 0007-1048.

Sokol, L., \& Loughran, T. P. (2006). Large granular lymphocyte leukemia. The oncologist, 11 (3), 263, ISSN 1083-7159.

Spitz, M., Sider, J., Johnson, C., Butler, J., Pollack, E., \& Newell, G. (1986). Ethnic patterns of Hodgkin's disease incidence among children and adolescents in the United States, 1973-82. Journal of the National Cancer Institute, 76 (2), 235, ISSN 02878874 .

Strickland, G. T. (2006). Liver disease in Egypt: hepatitis C superseded schistosomiasis as a result of iatrogenic and biological factors. Hepatology, 43 (5), 915-922, ISSN 10245332.

Strickler, H. D., Goedert, J. J., Devesa, S. S., Lahey, J., Fraumeni, J. F., \& Rosenberg, P. S. (2003). Trends in US pleural mesothelioma incidence rates following simian virus 40 contamination of early poliovirus vaccines. Journal of the National Cancer Institute, 95 (1), 38, ISSN 0287-8874.

Sukpanichnant, S. (2004). Analysis of 1983 cases of malignant lymphoma in Thailand according to the World Health Organization classification. Human pathology, 35 (2), 224-230, ISSN 0046-8177.

Sukpanichnant, S., Sonakul, D., Piankijagum, A., Wanachiwanawin, W., Veerakul, G., Mahasandana, C., et al. (1998). Malignant lymphoma in Thailand. Cancer, 83 (6), 1197-1204, ISSN 1097-0142.

Swerdlow, A. J. (2003). Epidemiology of Hodgkin's disease and non-Hodgkin's lymphoma. European Journal of Nuclear Medicine and Molecular Imaging, 30 (0), S3-S12, ISSN 16197070 .

Takatsuki, K. (1990). Adult T-cell leukemia/lymphoma. Adult T-Cell Leukaemia in Japan: A Special Issue of the Journal Hematology Reviews and Communications, 201, ISBN-13:9783718649334.

Tarhini, M., Kchour, G., Zanjani, D. S., Rafatpanah, H., Otrock, Z. K., Bazarbachi, A., et al. (2009). Declining tendency of human T cell leukaemia virus type I carrier rates among blood donors in Mashhad, Iran. Pathology, 41 (5), 498, ISSN 00313025.

Thomas, R., Re, D., Zander, T., Wolf, J., \& Diehl, V. (2002). Epidemiology and etiology of Hodgkin's lymphoma. Annals of Oncology, 13 (suppl 4), 147, ISSN 09237534.

Thu, G. O., Hem, L. Y., Hansen, S., Møller, B., Norstein, J., Nøkleby, H., et al. (2006). Is there an association between SV40 contaminated polio vaccine and lymphoproliferative 
disorders? An age-period-cohort analysis on Norwegian data from 1953 to 1997. International journal of cancer, 118 (8), 2035-2039, ISSN 0020-7136.

Uchiyama, T., Yodoi, J., Sagawa, K., Takatsuki, K., \& Uchino, H. (1977). Adult T-cell leukemia: clinical and hematologic features of 16 cases. Blood, 50 (3), 481, ISSN 0006-4971.

Vallisa, D., Bernuzzi, P., Arcaini, L., Sacchi, S., Callea, V., Marasca, R., et al. (2005). Role of anti-hepatitis $\mathrm{C}$ virus $(\mathrm{HCV})$ treatment in $\mathrm{HCV}$-related, low-grade, B-cell, nonHodgkin's lymphoma: a multicenter Italian experience. Journal of Clinical Oncology, 23 (3), 468, ISSN 0732-183X.

Vilchez, R. A., Madden, C. R., Kozinetz, C. A., Halvorson, S. J., White, Z. S., Jorgensen, J. L., et al. (2002). Association between simian virus 40 and non-Hodgkin lymphoma. The Lancet, 359 (9309), 817-823, ISSN 0140-6736.

Vineis, P., Crosignani, P., Sacerdote, C., Fontana, A., Masala, G., Miligi, L., et al. (1999). Hematopoietic cancer and peptic ulcer: a multicenter case-control study. Carcinogenesis, 20 (8), 1459, ISSN 0143-3334.

Vose J, Armitage J, Weisenburger D. (2008) International peripheral T cell and natural killer T cell lymphoma study: pathology findings and clinical outcomes. Journal clinical oncology, 26 (25),4124-4130, ISSN 0732-183X.

Wang, J., Young, L., Win, W., \& Taylor, C. R. (2005). Distribution and ZAP-70 expression of WHO lymphoma categories in Shanxi, China: a review of 447 cases using a tissue microarray technique. Applied Immunohistochemistry \& Molecular Morphology, 13 (4), 323, ISSN 1062-3345.

Ward, M. H., Hoar Zahm, S., Weisenburger, D. D., Gridley, G., Cantor, K. P., Saal, R. C., et al. (1994). Dietary factors and non-Hodgkin's lymphoma in Nebraska (United States). Cancer Causes and Control, 5 (5), 422-432, ISSN 0957-5243.

Weisenburger, D. D. (1994). Epidemiology of non-Hodgkin's lymphoma: Recent findings regarding an emerging epidemic. Annals of Oncology, 5 (suppl 1), S19-S24, ISSN 0923-7534.

Wilson, K., Freeland, J., Gallagher, A., Cosby, S., Earle, J., Alexander, F., et al. (2007). Measles virus and classical Hodgkin lymphoma: no evidence for a direct association. International journal of cancer, 121 (2), 442-447, ISSN 0020-7136.

Wotherspoon, A., Diss, T., Pan, L., Isaacson, P., Doglioni, C., Moschini, A., et al. (1993). Regression of primary low-grade B-cell gastric lymphoma of mucosa-associated lymphoid tissue type after eradication of Helicobacter pylori. The Lancet, 342 (8871), 575-577, ISSN 0140-6736.

Yamaguchi, K. (1994). Human T-lymphotropic virus type I in Japan. The Lancet, 343 (8891), 213-216, ISSN 0140-6736.

Yanagihara, E. T., Blaisdell, R. K., Hayashi, T., \& Lukes, R. J. (1989). Malignant lymphoma in Hawaii Japanese: A retrospective morphologic survey. Hematological oncology, 7 (3), 219-232, ISSN 0278-0232.

Zarate Osorno, A., Roman, L. N., Kingma, D. W., Meneses Garcia, A., \& Jaffe, E. S. (1995). Hodgkin's disease in Mexico. Prevalence of Epstein Barr virus sequences and correlations with histologic subtype. Cancer, 75 (6), 1360-1366, ISSN 10970142 . 
Zhang, S., Hunter, D. J., Rosner, B. A., Colditz, G. A., Fuchs, C. S., Speizer, F. E., et al. (1999). Dietary fat and protein in relation to risk of non-Hodgkin's lymphoma among women. Journal of the National Cancer Institute, 91 (20), 1751, ISSN 0027-8874.

Zucca, E. (2008). Extranodal lymphoma: a reappraisal. Annals of Oncology, 19 (suppl 4), iv77, ISSN 0923-7534.

Zucca, E., Roggero, E., Maggi-Solcà, N., Conconi, A., Bertoni, F., Reilly, I., et al. (2000). Prevalence of Helicobacter pylori and hepatitis $\mathrm{C}$ virus infections among nonHodgkin's lymphoma patients in Southern Switzerland. haematologica, 85 (2), 147, ISSN 0390-6078. 


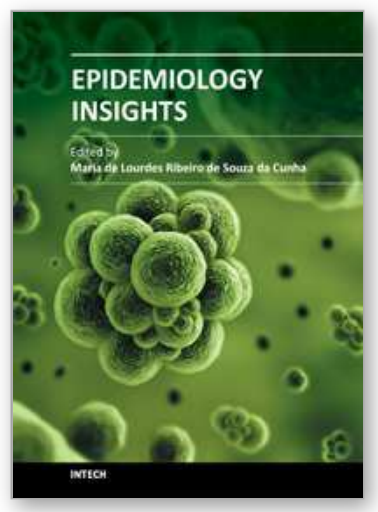

\author{
Epidemiology Insights \\ Edited by Dr. Maria De Lourdes Ribeiro De Souza Da Cunha
}

ISBN 978-953-51-0565-7

Hard cover, 396 pages

Publisher InTech

Published online 20, April, 2012

Published in print edition April, 2012

This book represents an overview on the diverse threads of epidemiological research, brings together the expertise and enthusiasm of an international panel of leading researchers to provide a state-of-the art overview of the field. Topics include the epidemiology of dermatomycoses and Candida spp. infections, the epidemiology molecular of methicillin-resistant Staphylococcus aureus (MRSA) isolated from humans and animals, the epidemiology of varied manifestations neuro-psychiatric, virology and epidemiology, epidemiology of wildlife tuberculosis, epidemiologic approaches to the study of microbial quality of milk and milk products, Cox proportional hazards model, epidemiology of lymphoid malignancy, epidemiology of primary immunodeficiency diseases and genetic epidemiology family-based. Written by experts from around the globe, this book is reading for clinicians, researchers and students, who intend to address these issues.

\title{
How to reference
}

In order to correctly reference this scholarly work, feel free to copy and paste the following:

Zahra Mozaheb (2012). Epidemiology of Lymphoid Malignancy in Asia, Epidemiology Insights, Dr. Maria De Lourdes Ribeiro De Souza Da Cunha (Ed.), ISBN: 978-953-51-0565-7, InTech, Available from: http://www.intechopen.com/books/epidemiology-insights/epidemiology-of-lymphoid-malignancy-in-asia

\section{INTECH}

open science | open minds

\section{InTech Europe}

University Campus STeP Ri

Slavka Krautzeka 83/A

51000 Rijeka, Croatia

Phone: +385 (51) 770447

Fax: +385 (51) 686166

www.intechopen.com

\section{InTech China}

Unit 405, Office Block, Hotel Equatorial Shanghai

No.65, Yan An Road (West), Shanghai, 200040, China

中国上海市延安西路65号上海国际贵都大饭店办公楼 405 单元

Phone: +86-21-62489820

Fax: +86-21-62489821 
(C) 2012 The Author(s). Licensee IntechOpen. This is an open access article distributed under the terms of the Creative Commons Attribution 3.0 License, which permits unrestricted use, distribution, and reproduction in any medium, provided the original work is properly cited. 